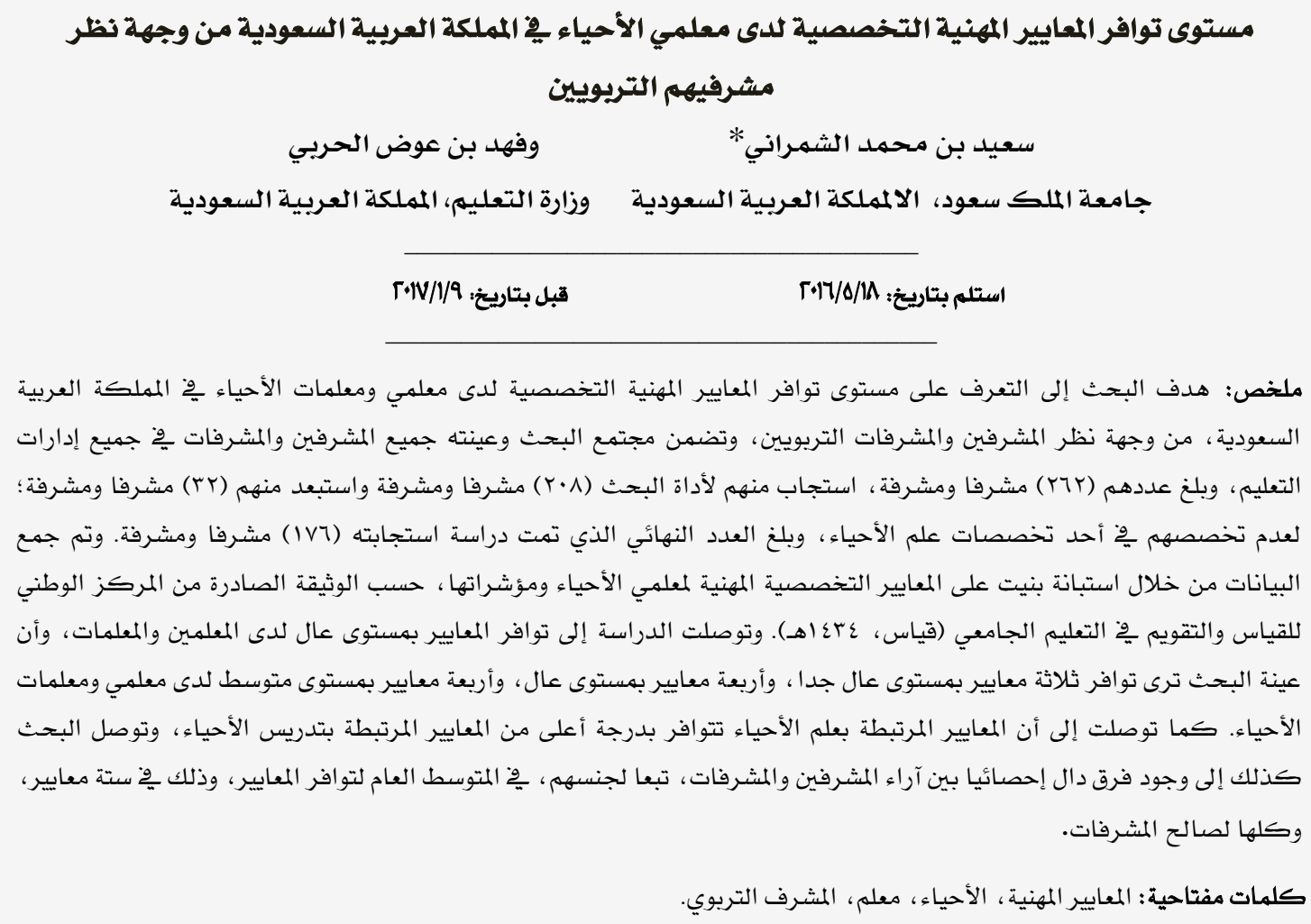

\title{
The Possession level of the Specialized Professional Standards in Saudi Biology Teachers from their Supervisors' Point of views
}

\author{
Saeed M. Alshamrani* \\ \& Fahad A. Alharbi \\ King Saud University, Saudi Arabia \\ Ministry of Education, Saudi Arabia
}

\begin{abstract}
Abstract. This paper aimed to identify how biology male and female teachers possess professional biology standards from their supervisors' point of view. The population and sample included all male and female supervisors in all educational districts in Saudi Arabia (N=262). Only 208 of them responded; and 32 of this number were excluded since they did not provide their specialization or they were not specialized in biology. The data was collected through a questionnaire constructing based on the standards and indicators included in the Professional Biology Standards for Biology teachers developed by the National Center for Assessment in Higher Education (Qias, 1434). The result indicated a high possession for the standards for male and female biology teachers; however, as individual standard, the result indicated that three of them had very high possession, four of them had high possession, and four of them had moderated possession. It also indicated higher possession for standards related to biology comparing with standards related to teaching. It was found also that there were significant differences between the responses of males and females supervisors in the total mean and on the means of six out of the eleven standards.
\end{abstract}

Keywords: Professional standards, biology, teacher, educational supervisor.

*sshamrani@KSU.EDU.SA 
للمعلّم، وومن أبـرز هــذه الاتجاهــات مفهـوم

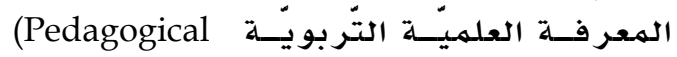
Content Knowledge PCK)

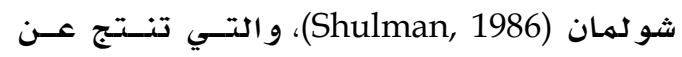

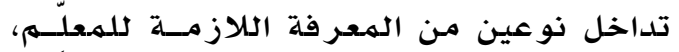

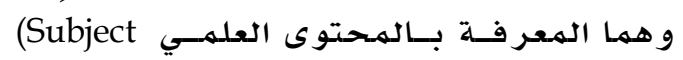

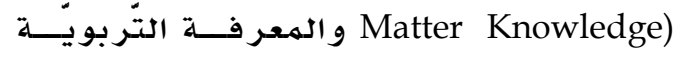

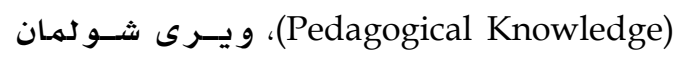

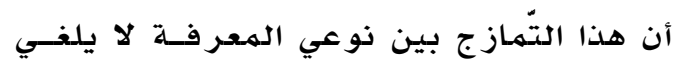

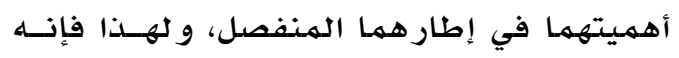

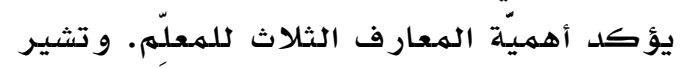

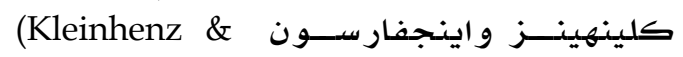
إلـــى أن شـــو لمـان أحسـد Ingvarson, 2007) تأثيرًا لافتًا في البحث التَّربوي، حيت تحسوّل

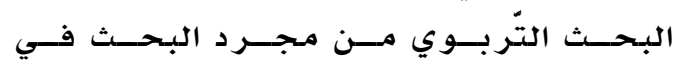

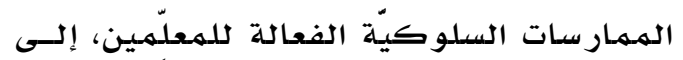

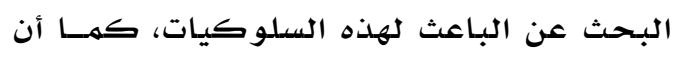

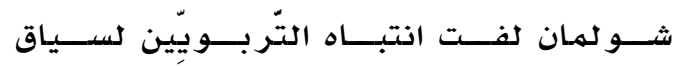

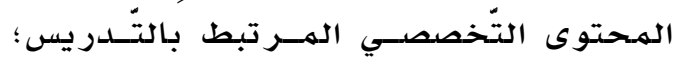

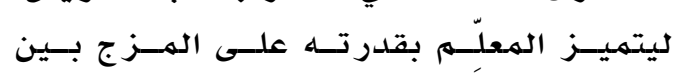

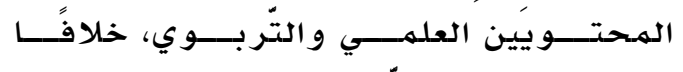

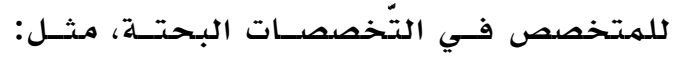

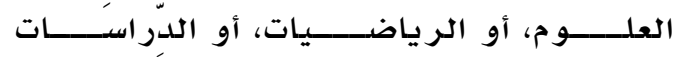

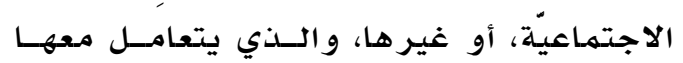
المتخصص فيها كمعار ف مجر دة.

وحاول مـجموعة من المتتخصصين التَّربِّين

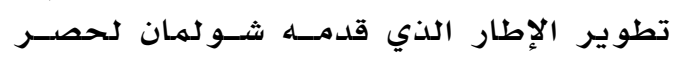
أنواع المعارف التي يتطلبها التّدريس، و منهها

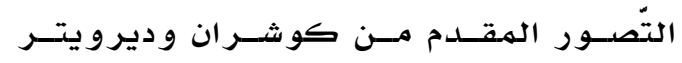
وكينج (Cochran, DeRuiter, \& King, 1993)، حيث يرون أربع معارف لازمة للهعلِّم، وهي:

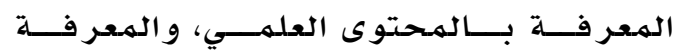

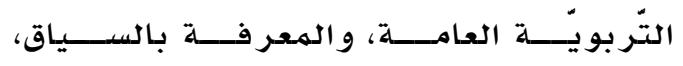

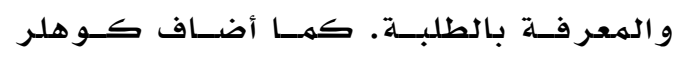
و ميشـرا (Kohler \& Mishra, 2008) مفهـوم

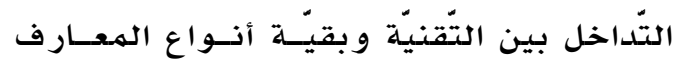

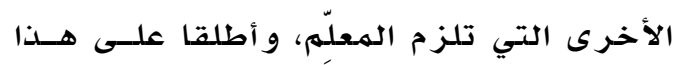

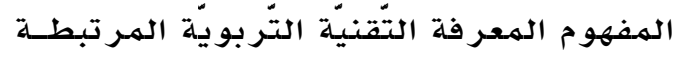

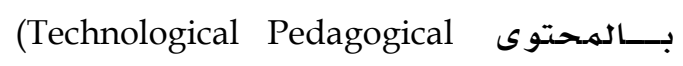
Content Knowledge TPACK)

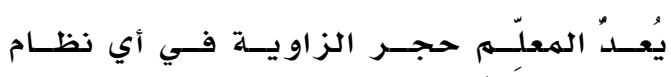

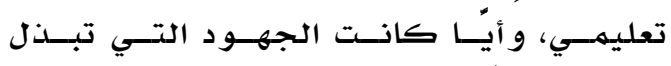

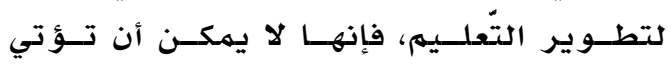

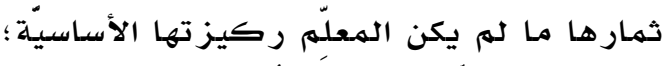

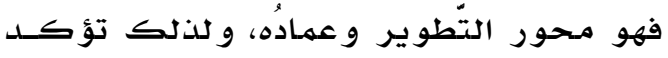

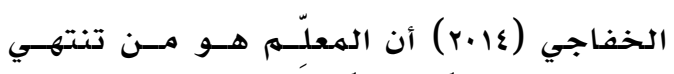

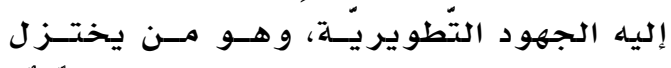

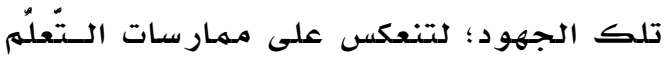

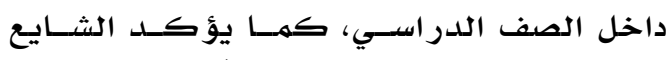

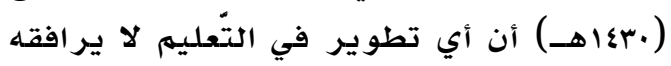

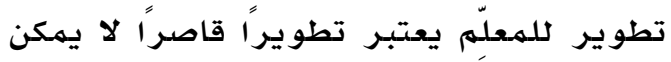

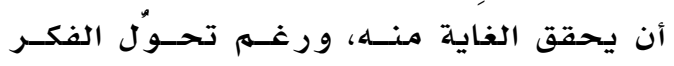

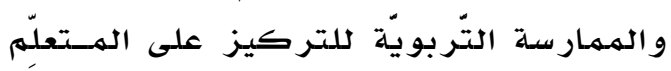

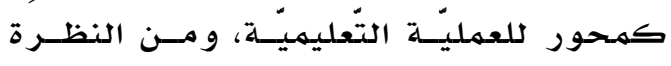

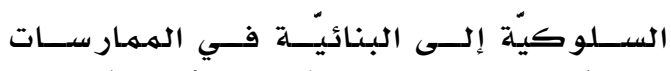

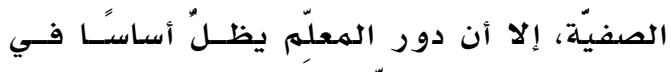

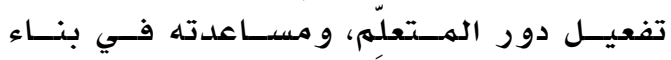

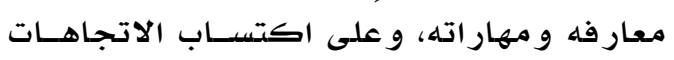

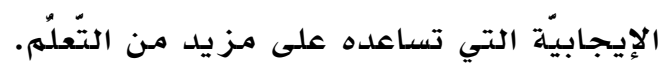
و تشير دانيلسون (Danielson, 1996) إلى تعقّد

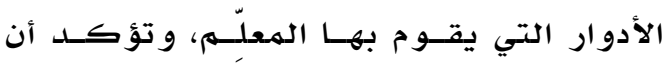

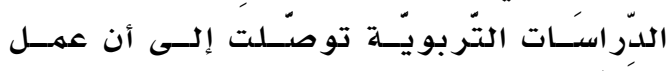
الهعلّم يتطلب اتخاذ أكثر مـن ثلاثــة آلاف

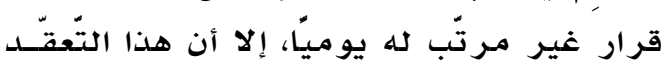

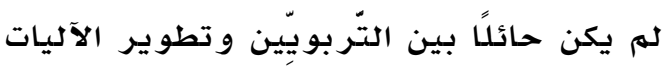

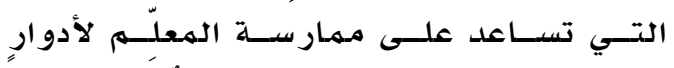

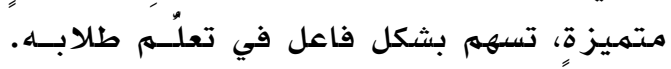

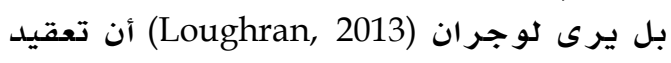

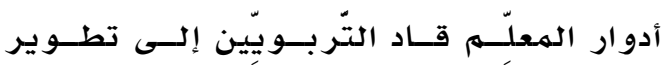

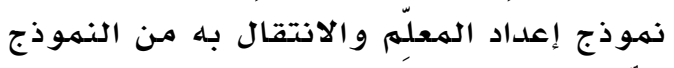

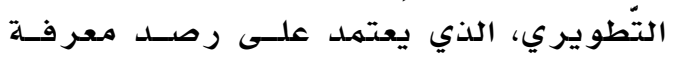

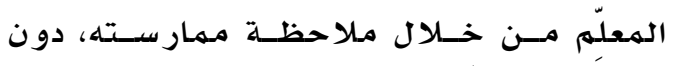

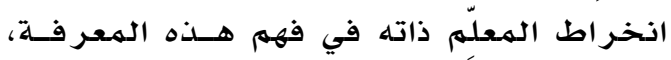
و استبدال هذا النهموذج بالنهموذج الهمهني الذي

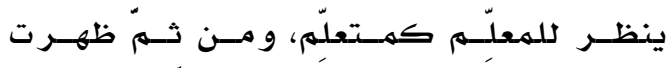

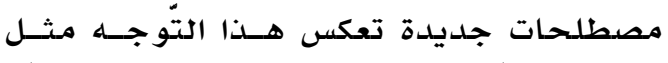

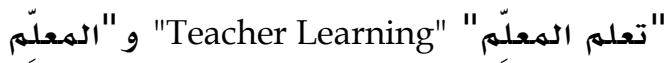

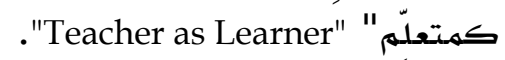
كما ظهر العديد مــن الاتجاهـات التّربويّــة

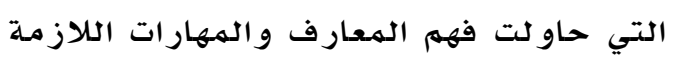




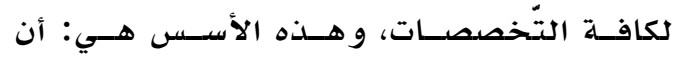

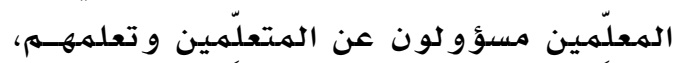

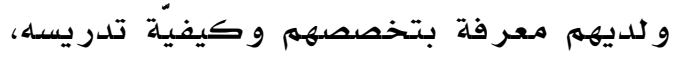

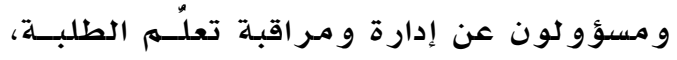

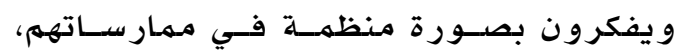

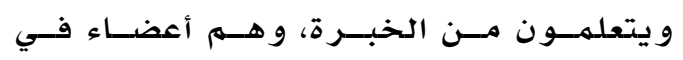

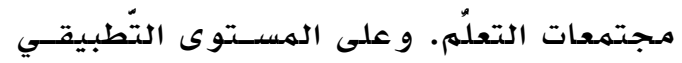

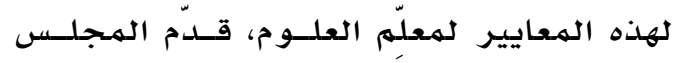

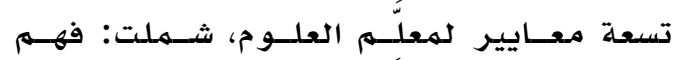

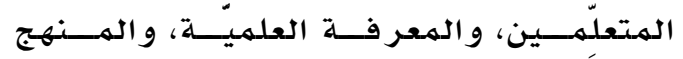

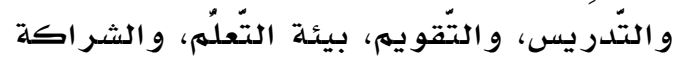

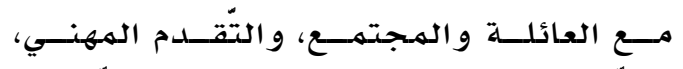

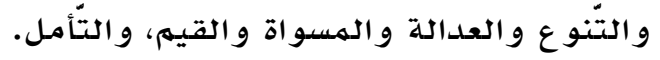

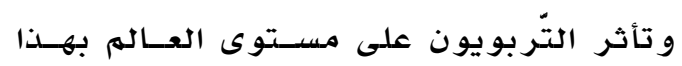

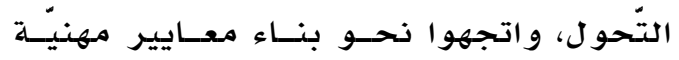

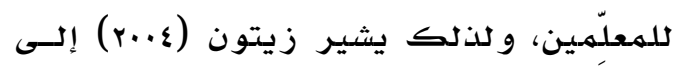

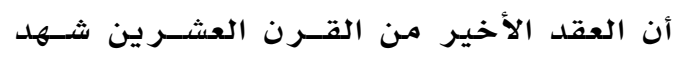

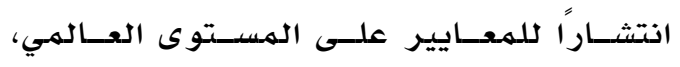

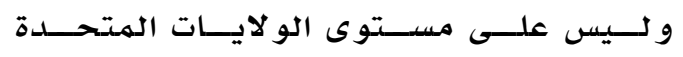

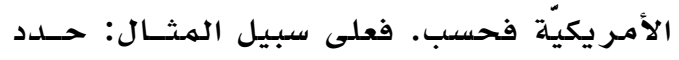

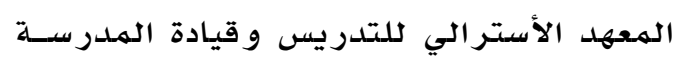
(Australian Institute for Teaching and School Leadership AITSL, n.d.) معايير مهنيّة رئيسة للمعلّمِين، يندرج تحتها

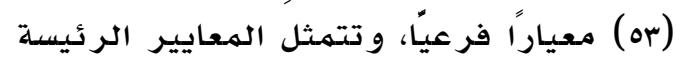

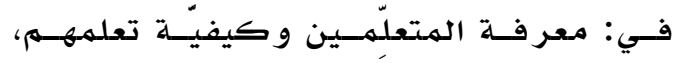

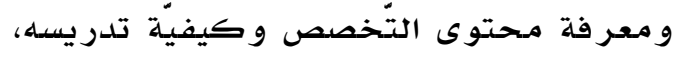

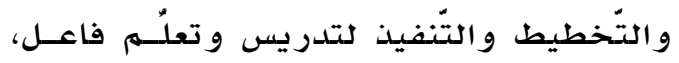

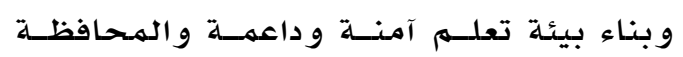

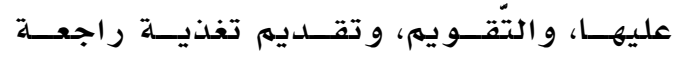

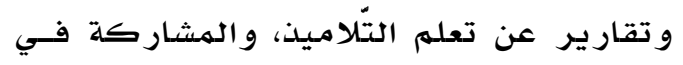

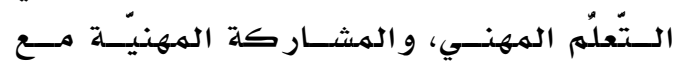

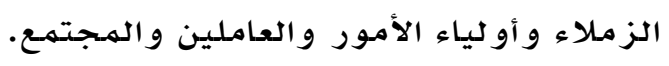
و لهم تكن المملكة العربيّهة السـعوديّة- كمهـا

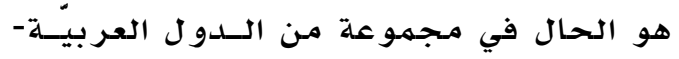

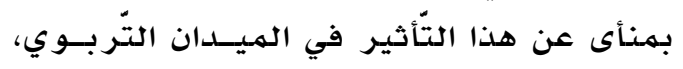

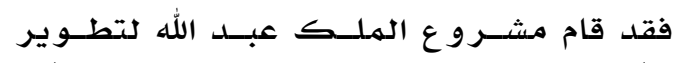

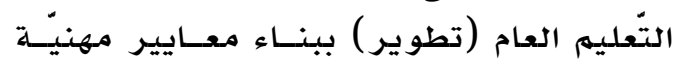

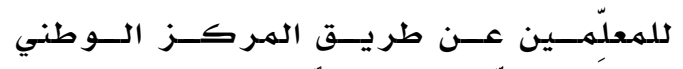
للقياسَ والتَّويم في التَعليم العالي (قياس)،
الإطار في تطورٍ مستمرِّ؛ لمعالجة التَحسديات

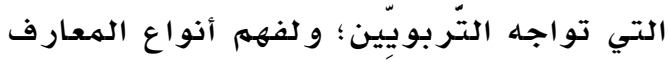

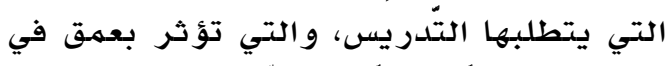
الممار سات التَدر يسيَّة للمعلّمِين. كما ظهرت اتجاهات جديــدة علسى مسـتوى التهري

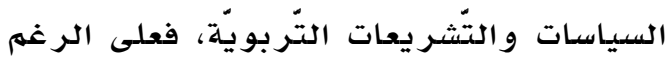

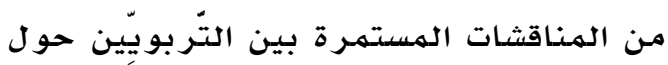

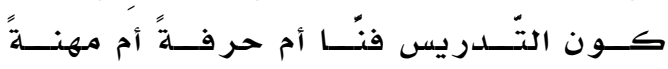

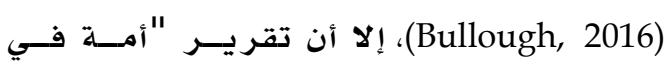

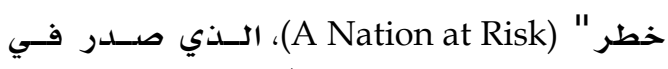

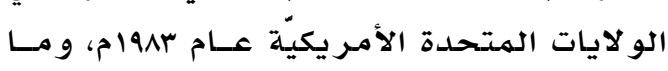

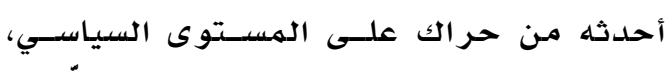

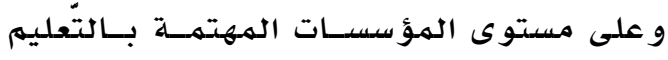

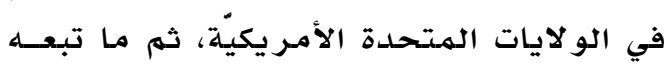

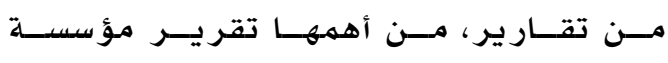

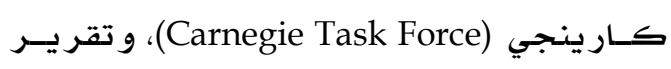

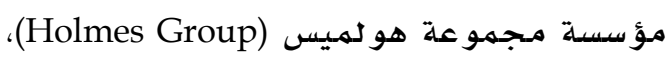

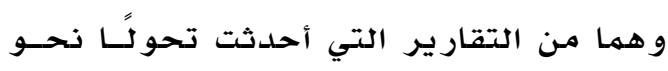

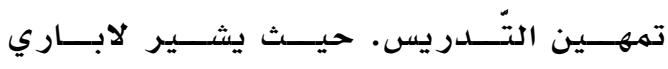

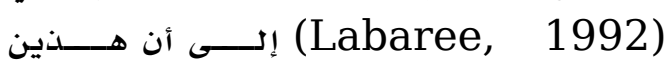

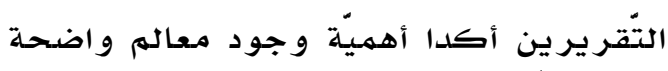

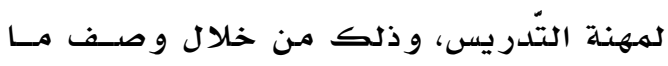

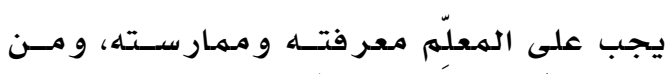

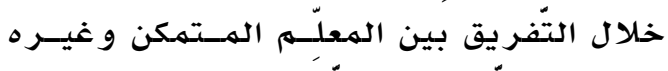

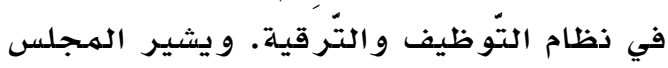

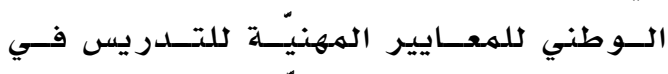

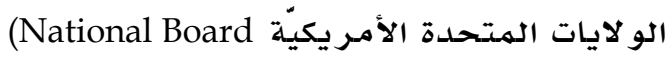
for Professional Teaching Standards إلى أن هذين التّقرير ين أسهما NBPTS, n.d.)

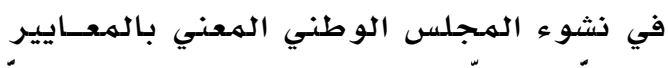

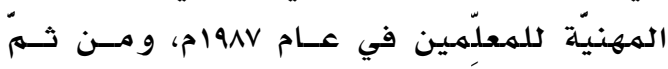

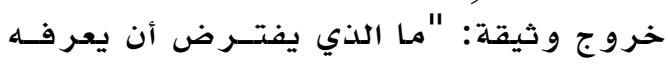

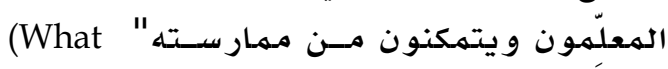
،teachers should know and be able to do) والتي كانت أساسًا بني عليه مسا بعسدها مسن

$$
\text { معايير مهنيّة. }
$$

وقدم المجلـس الـوطني للمعــيـير المهنيــة

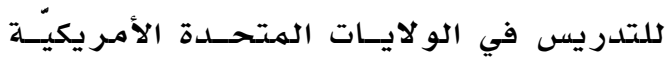

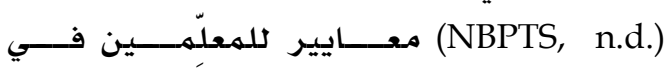

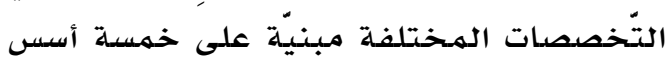


للمعسايير الههنيّـة للتسـدريس فـي الولايـات

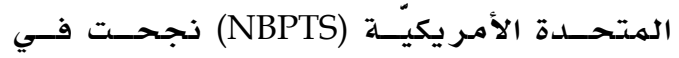

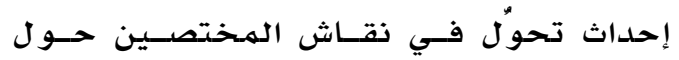

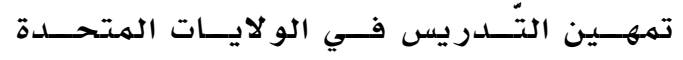

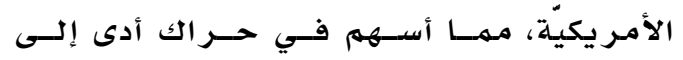

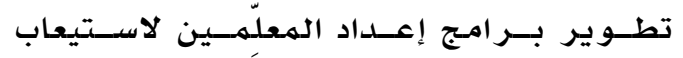

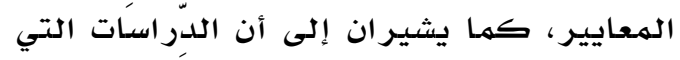

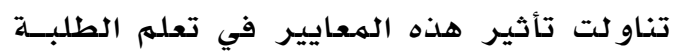

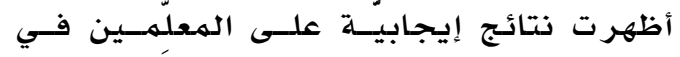

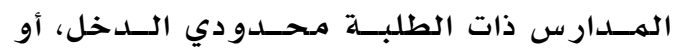

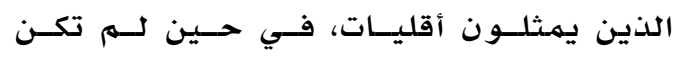

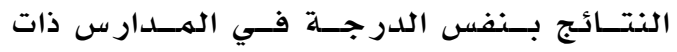

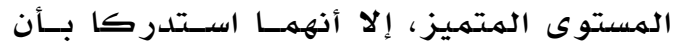

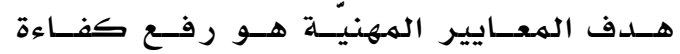

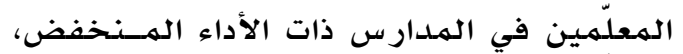

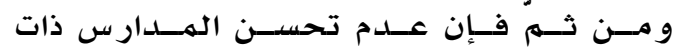

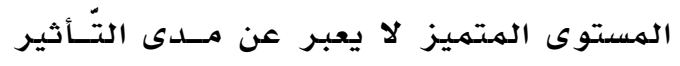

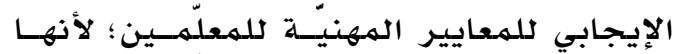

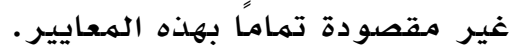

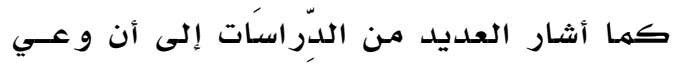

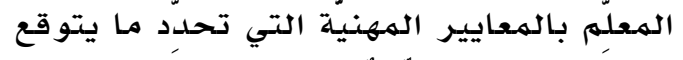

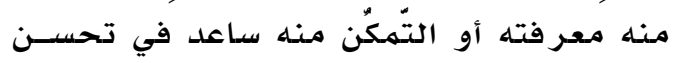

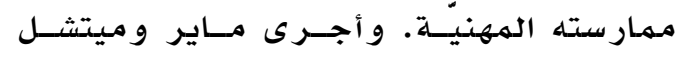

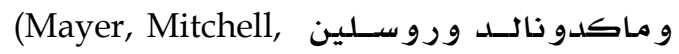
Macdonald, \& Roslyn, 2005)

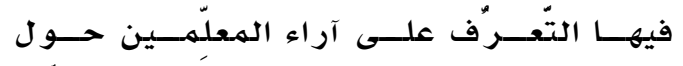

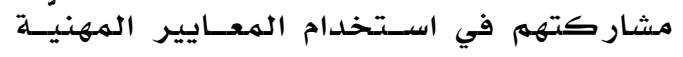

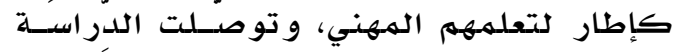

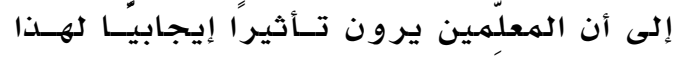

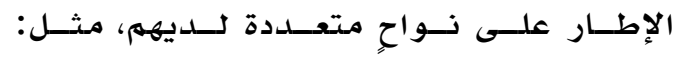
اكتسـاب معرفة أعمق بهذه الهعايير، و تحسن

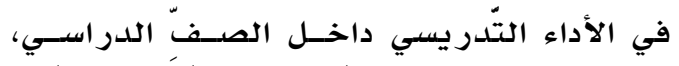

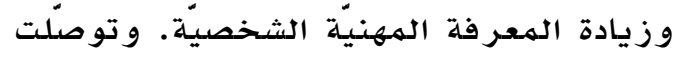

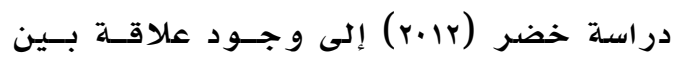

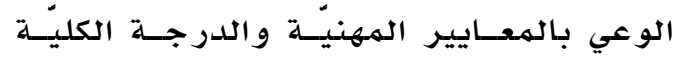
للهمارسات المهنيّة للمعلّم.

و تشير كلينهينز وإينجفارسون Kleinhenz) (إلى أن الهعايير المهنيّة Ingvarson, 2007)

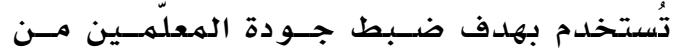

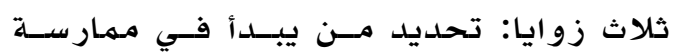

و تضمنت هذه المعايير بنيـة موحسدة تشــمل جــز أين أسـاسـيـين، همــا: الهعــايير العامسـة

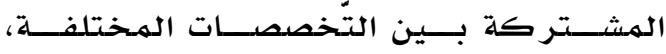

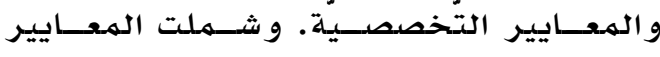

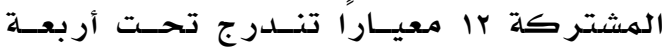

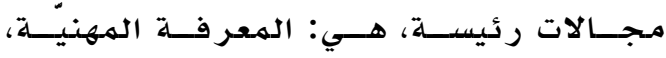

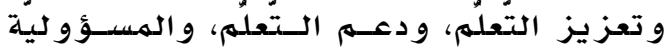
الههنيسـة، فـي حسين يتبــاين عـدد الهعـايير التخصصية من تخصص إلـى آخــر، إلا أذهـا

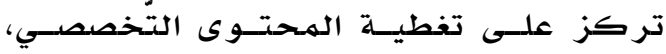
وكيفيّة تدريسه (قياس، سمعاهـ).

و قدمت وثيقة معايير معلّمي الأحياء (قياس،

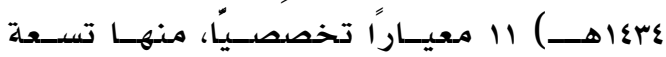

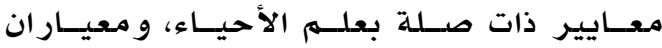
متصلان بتدريس الأحياء، و تضمنت المعـايير

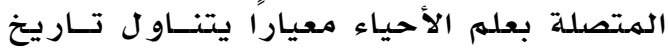

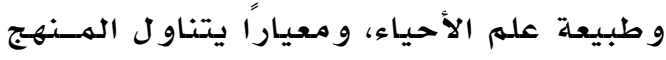

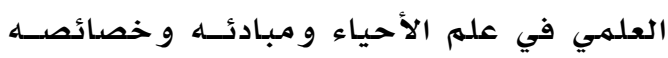

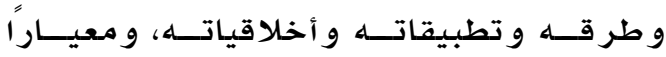

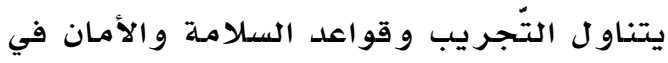

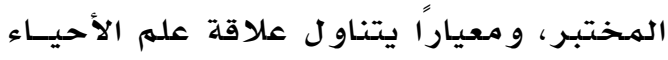

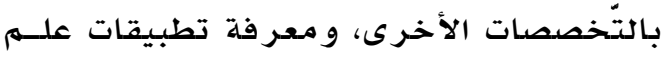

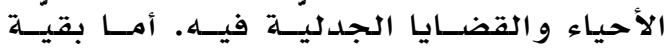

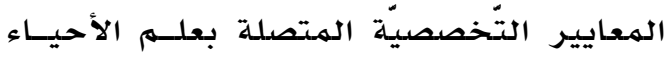
فتناو لت جوانسب المـحتــوى العلمــي للأحيـاء

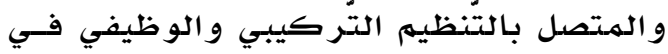

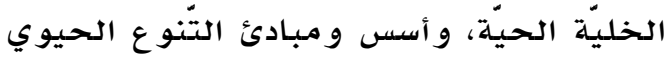

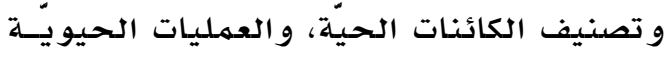

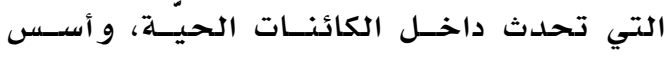

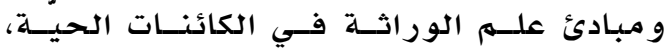
و أسس و مبادئ علهم البيئة و الأنظمسـة البيئيسـة

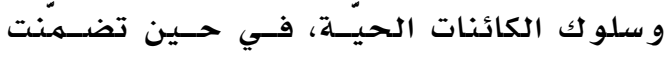
المعايير المتعلقة بتـدريس الأحيـاء معيـارًا

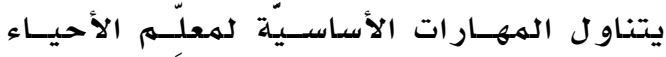

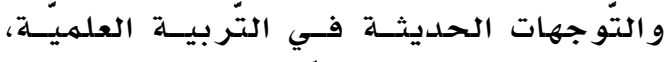
و آخر يتناول طرائق التدريس الخاصسـة فـي لئي التّربية العلميَّة.

و في سياق تأثير المعايير المهنيّة للمعلّهــين، فيشير بويسد وريـس (Boyd \& Reese, 2006) إلى أن الهعايير التي قدمها المجلس الوطني 


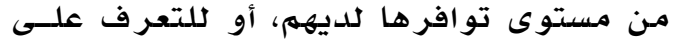

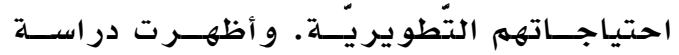

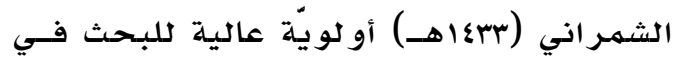

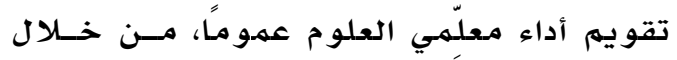

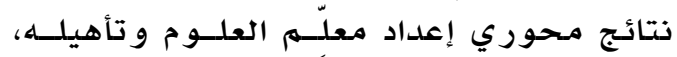

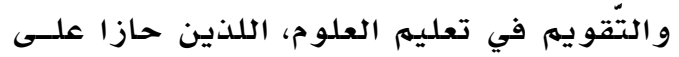

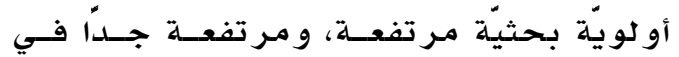

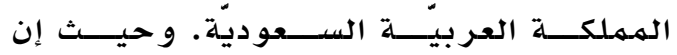

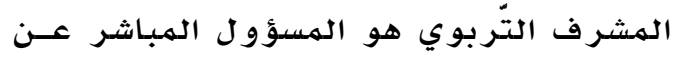

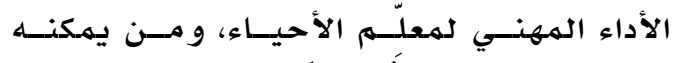

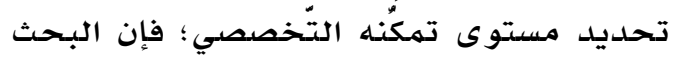

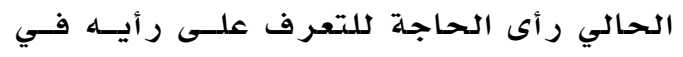

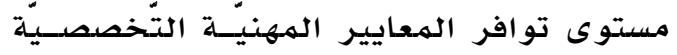

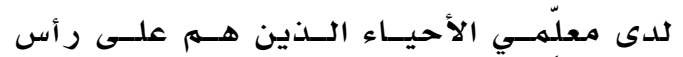
العمل لديله.

أسئلة الدراسة

ا. مـا مســتوى تــوافر المعـايير المهنيــة

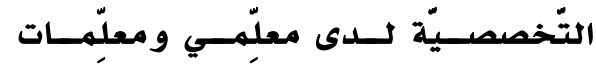

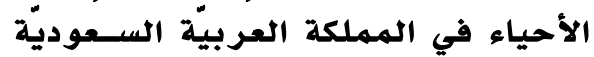

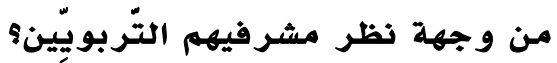
r. هل توجد فروق ذات دلالــة إحصـائية

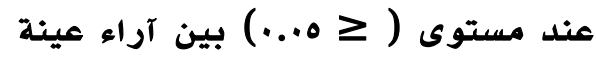

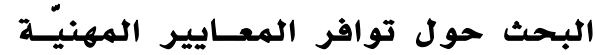

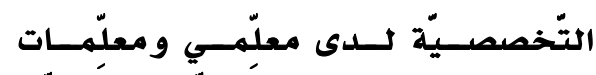

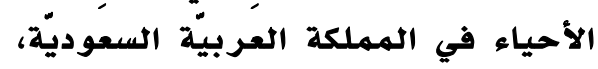
تُعزى لمتغير الجنسو

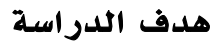

هدف البـحـث الحــالي إلـى معر فــة مســتوى

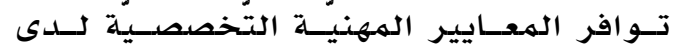

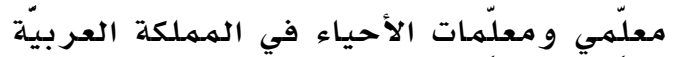

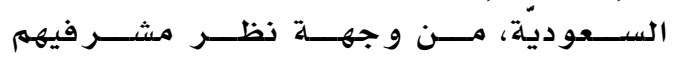
التّر بويِين.

أهمية الدراسة

تتجلى أهميّة البحث في عدة جوانب، وهي: ا. أهميّة المعايير المهنيّة لمعلّمِي الأحياء

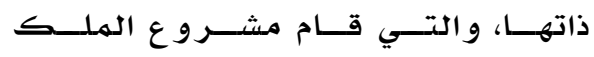

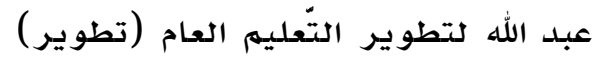

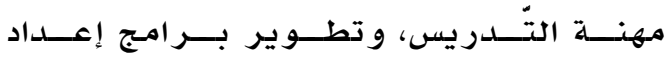

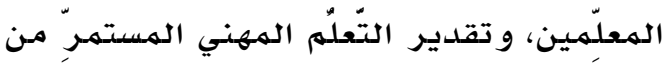

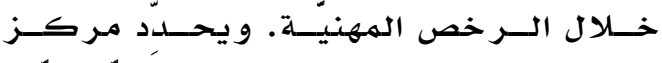

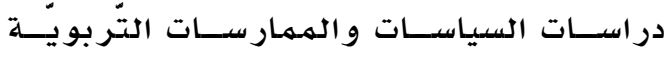
(Centre of Study for Policies and Practices in Education CEPPE) الههنيّة بصورة أوسع، حيث يرى أنهـا تفيـد التهديد

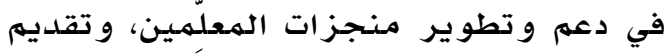

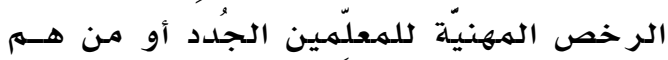

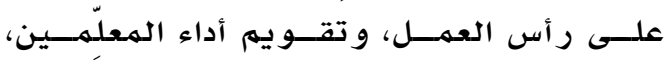
وتفيد في تقويه ومنح الاعتمهـاد الأكـاديهي

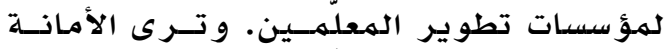

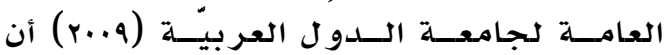

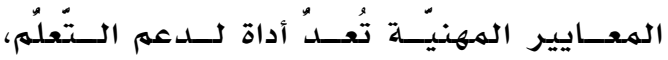

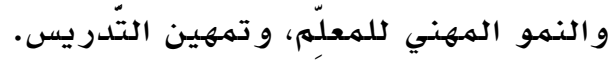

مشكلة الدراسة

يؤكـد إنجافيرسـون (Ingvarson, 1998) أن

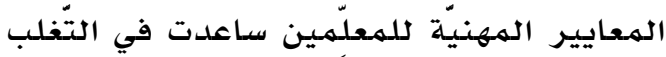

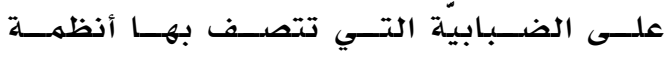

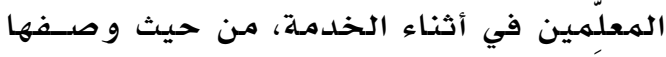

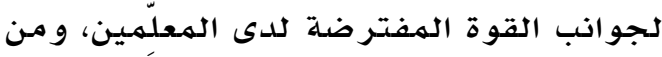

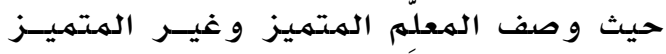

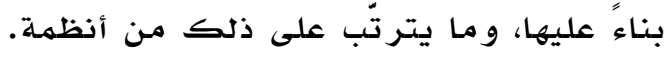

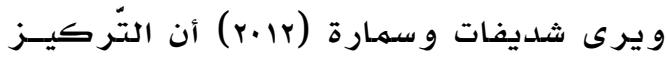

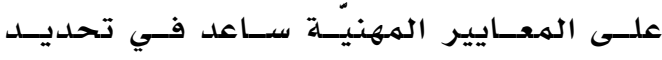

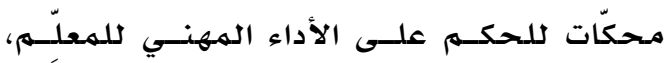
و في رفع مستوى المحاسبيّة و المسؤو ليّة.

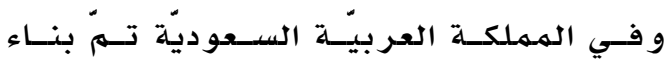

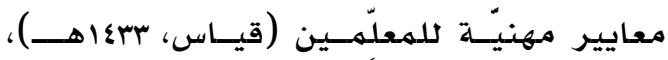
كما خرجت و ثائق معسايير تغطـي الجانـب مهابـ

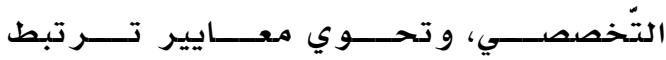

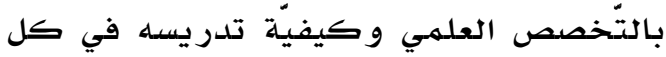
تخصص، و من ضهمن هذه الوثـائق (المعـايير

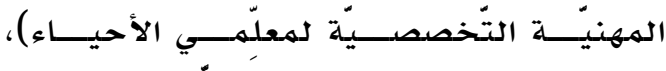

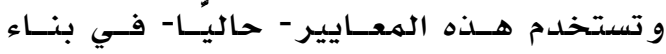

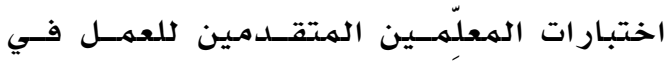
تدريس مقررات الأحياء، إلا أن هذه الهعايير

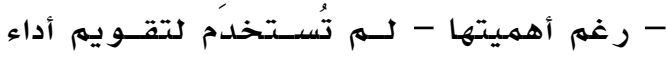
المعلّمين الحاليين على رأس العمل، للتأكسد 
مصطلحات الدراسة

ا. المعايير المهنيْة التخخصصسيّة لمعلّمسي

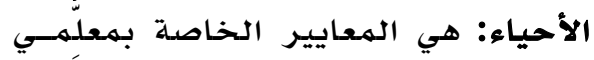

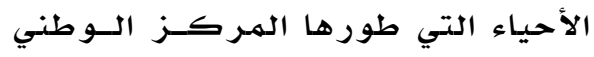

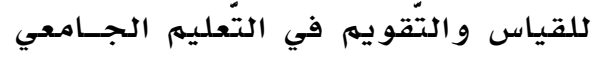

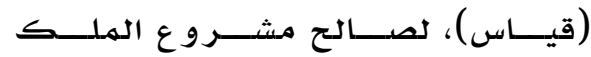

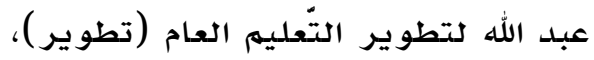

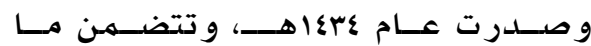

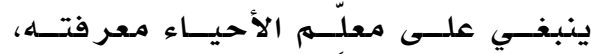
و القدرة على أدائه في تخصص الأحياء، وطرق تدريسـ، بما في ذلك المعسارف

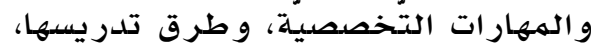

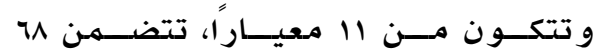
مؤشراً تندرج تحون تحتها (قياس، عبعاهــ)،

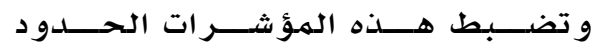
الهـعر فيّة لكل معيار .

r. المشرفون التّربويُون لمسادة الأحيـاء:

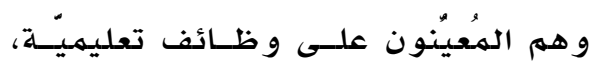

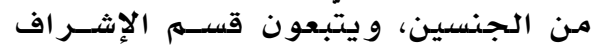

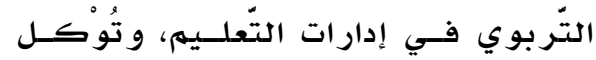

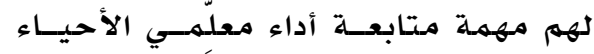

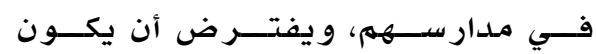

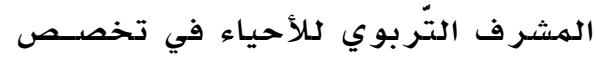

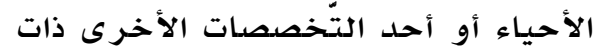

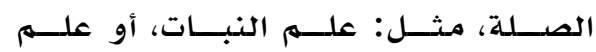

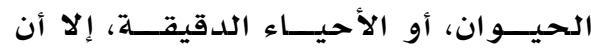

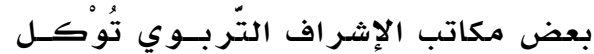

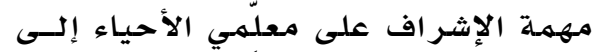

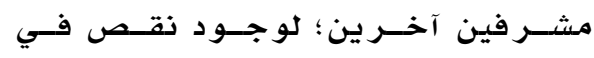

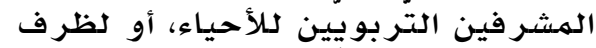

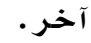
مستوى التّوافر: ويُقصد بها إجر ائيًا في

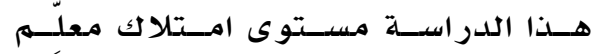

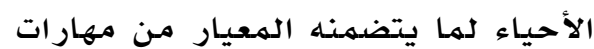

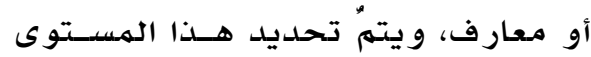

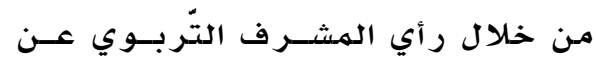
مستوى توافر مؤشـر ات الهـعيـار التــي

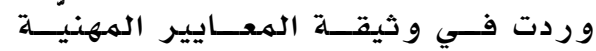

ببنائهها، مــن خـلال المـركـز الـوطني للقياس و التّقويم فـي التّعلـيهم العـالي

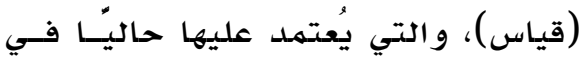

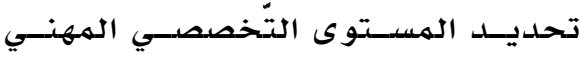

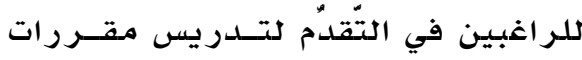
الأحياء في الهملكة العربيّة السـعوديّة، من خلال الاختبار الذي يجريه مركز

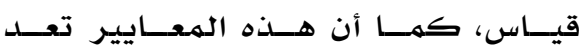

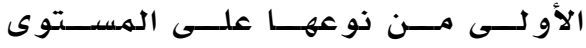

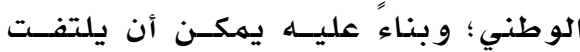

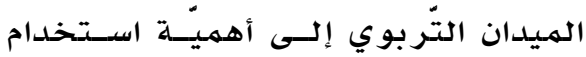

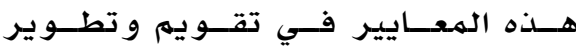
معلّمي الأحياء الحاليين، و توسيع مـجـال

استخخدامها.

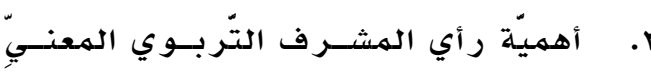

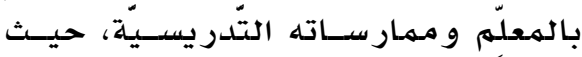

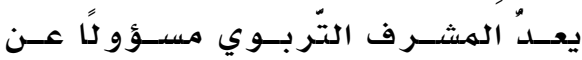

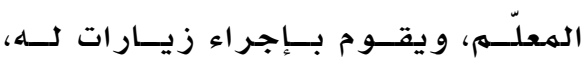

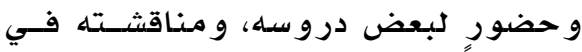

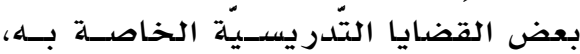
و لهذا فإن المشرف التّربوي هو الأجدر

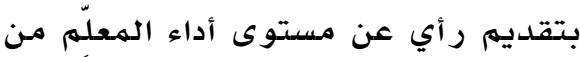
منظور تخصصي. r. قد تقيد نتـائج هــذا البـحـث الهعنيـين بتطوير معلمِهـي الأحيـاء فـي الهملكــة

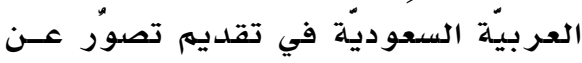

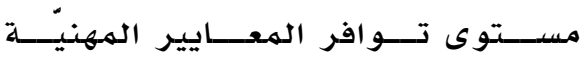

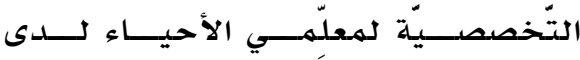

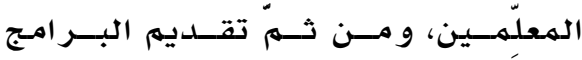

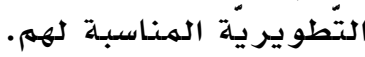

حدود الدراسة

اقتصر البـحسث علـى التَعـرِف علـى مســتوى

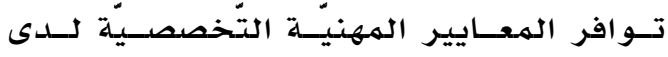

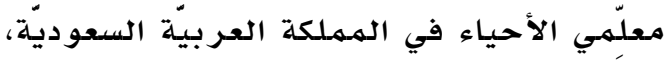
من وجهة نظر المشرفين التربويِين لهم، في الهي

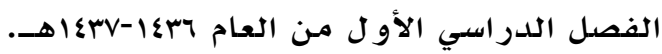




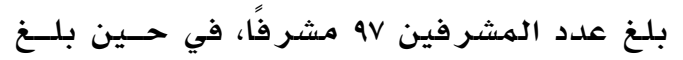

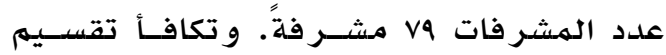

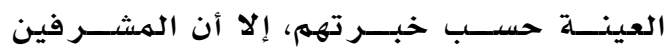

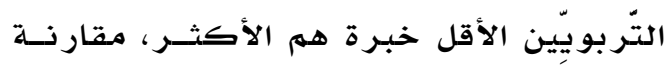
بجنسهم، في حين أن الهشرفات الأعلى خبرة

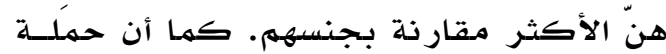

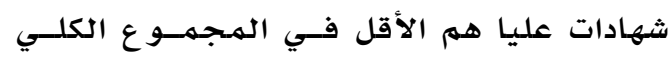
للعينة، ووفي كلا الجنسين. كما أن الفـارق

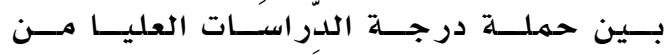

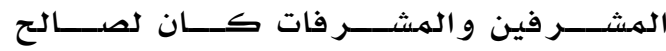
الهشرفين، و أغلب عينة البحث حاصلون ونهئ على

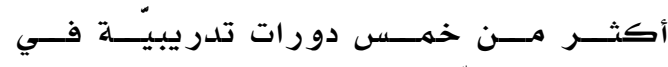

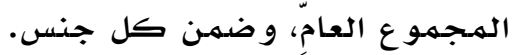

جدول 1

\begin{tabular}{|c|c|c|c|c|}
\hline المجموع & أنثى & ذكر & كات الآتغيرغراقية لعينه & \\
\hline$\wedge \wedge$ & re & 01 & • ـ اسنوات وأقل & الخبرة الخبرة \\
\hline$\wedge$ & $\varepsilon r$ & $\leqslant 7$ & أكثر من · ا سنوات & \\
\hline 187 & $\vee 9$ & $9 \vee$ & المجموع & \\
\hline 149 & $\vee \cdot$ & 09 & بكالوريوس & المؤهل \\
\hline$\varepsilon \varepsilon$ & $\wedge$ & rᄉ & دراسات عليا & \\
\hline ivo & $\vee \wedge$ & $9 \vee$ & المجموع & \\
\hline ro & $v$ & 11 & خمس دورات وأقل & الدورات ل \\
\hline 101 & Vr & $\vee q$ & أكثر من خمس دورات & التدريبية \\
\hline 184 & v9 & $9 \vee$ & المجموع & \\
\hline
\end{tabular}

أداة الدراسة

من أجل تحقيق هدف البحث، والإجابـة عـن تساؤ لاته؛ قام الباحثان بتطوير لهير استبانة مبنيّة

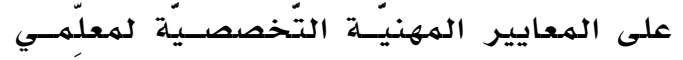

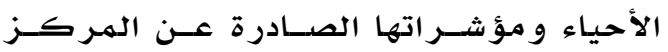

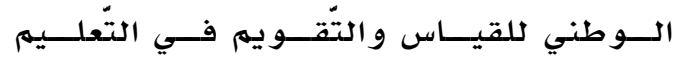

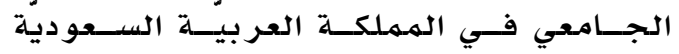

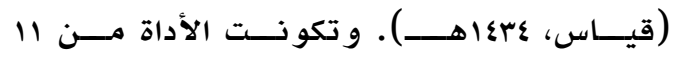

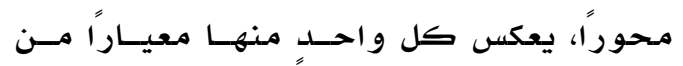

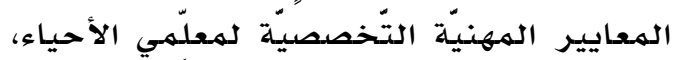

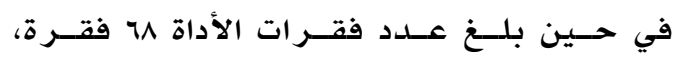
تعكس مؤشر ات المعايير الههنيّة التّخصصيّة،

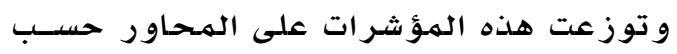

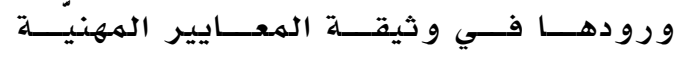

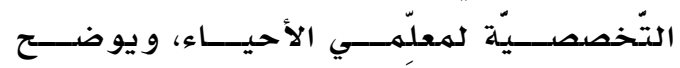

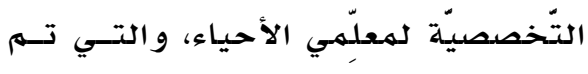

تضمينها في أداة البحث الحالي.

\section{الطريقة والإجر اءت}

استخدم البحث الهنهج الوصفي الذي يعتهــد

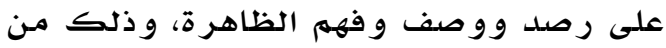

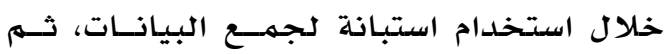
تحليلها لإجابة عن أسئلة البحث. مجتمع البحث وعيّنته

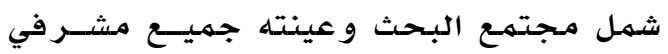
و مشرفات مادة الأحياء المتتخصصين في علهم

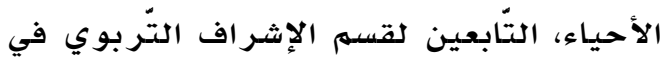

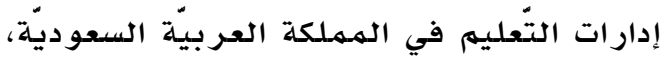

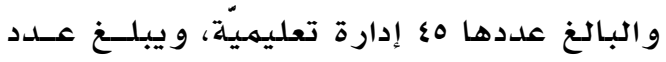

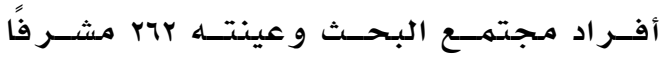

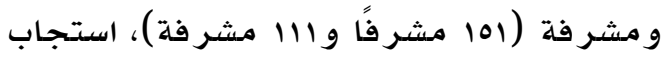

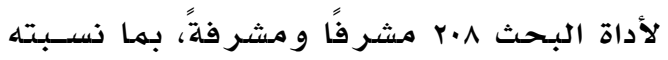

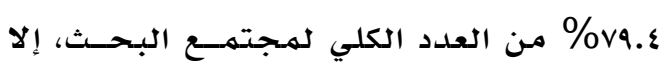

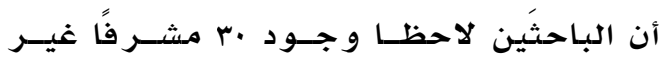

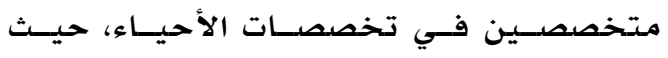
كانت تخصصاتهم إما فـي مـــالات العلــوم

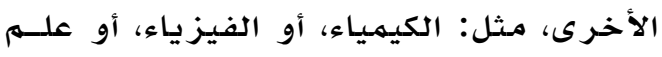

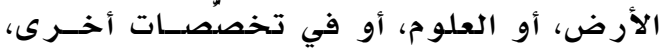

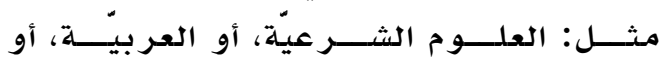

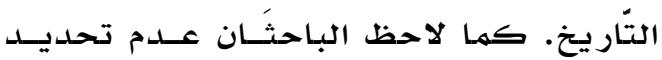

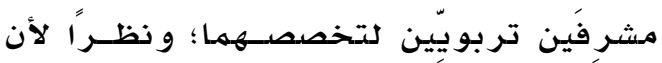

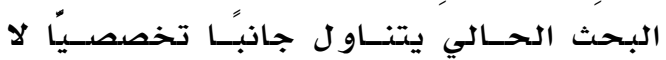
يمكن الإحاطة به من قبل غير المتخصصسين

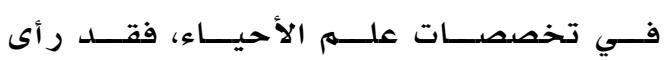

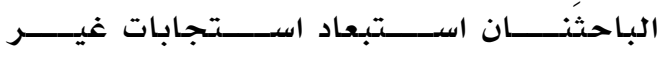

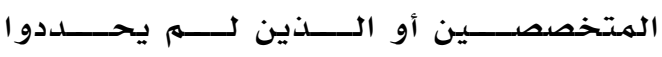

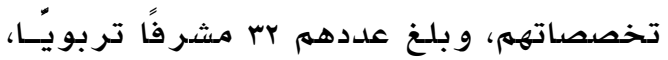

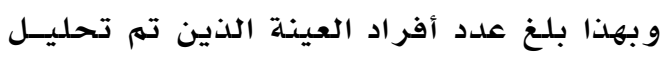

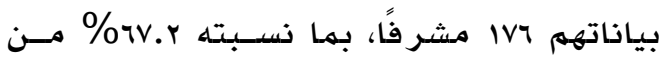

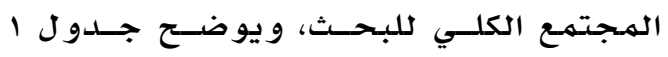
السهمات الديموو غر افيّة لهمه.

و يظهـــر الجــــدول لا أن عـــدد المشـــرفين

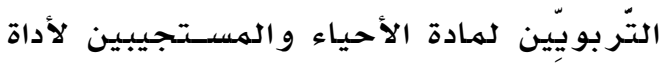

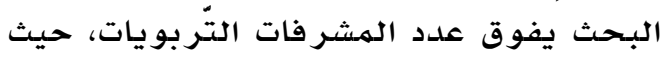


و أضـاف الباحثَــان جـزءءًا فـي مقدمــة الأداة،

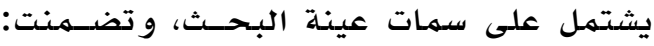

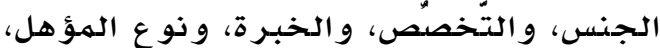

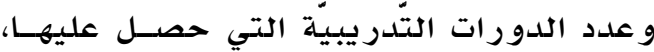
وحلددت مـجمو عة مسـن الخيـارات لكـل سـهمة

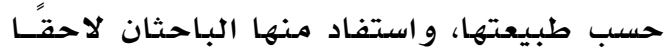
في ضبط وو صدف عينــة البحسـ، حيـث تـمى استبعاد بعض المستجبين بناء على مـا حددوه

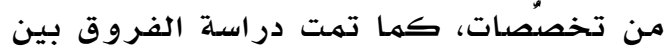

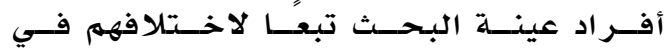
الجنس.

صدق أداة الدراسة للتأكد مـن الصــدق الظــاهري لــلأداة، تسم عـرض صــور تها الأو ليــة علــى ســبعة مــن

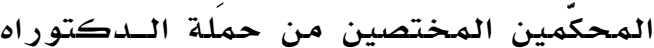

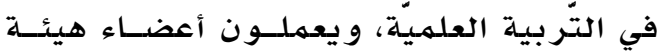

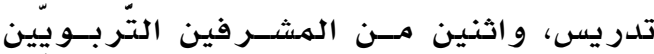
للعلوم في وزارة التُعليه، وثلاثسة مشــر فين

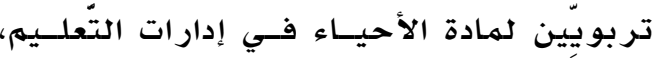

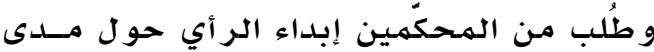
وضوح الأداة ككل، ومدى مناسبـة الهقيـاس اله

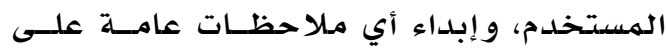
الأداة، في حسين لـهم تشـــل الهـر اجعــة التـي

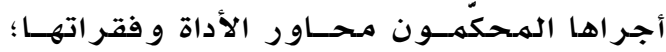

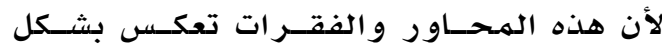

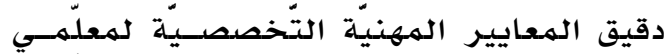

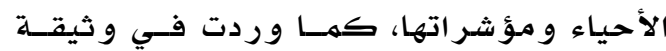

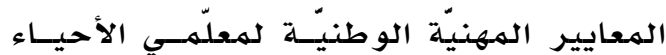

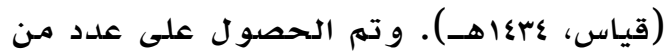

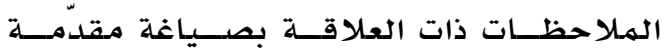

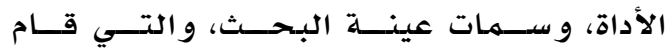

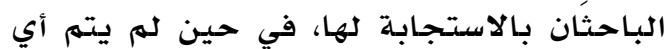

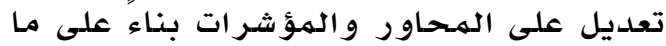
كتبـه بعض المحكمين من ملاحظات؛ لتتنافيه

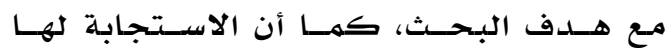

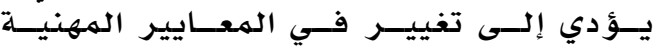
التخصصصية و مؤشئر اتها.

كما تم- بناء" على نتـائج التّطبيـق الفعلــي- التهاء حساب معامل الاتساق الــداخلي بــين الفقـرة
الجدول لج محاور الأداة، و عدد الفقر ات ضـمـن كل محور.

جدول ra ra

محاور أداة البحث، وعدد الفقرات تحت كل محور منها

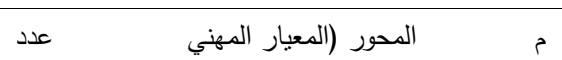

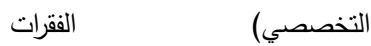
(المؤشرات) يعرف معلم الأحياء طبيعة علم الأحياء وتاريخ تطوره.

V لئم معلم الأحياء بمفهوم المنهج العلمي، ومبادئه، وخصائصده،

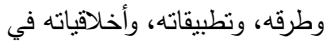

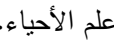

$7 \quad$ يجري معلم الأحياء التجارب العلمية

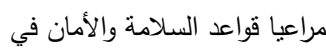

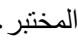

7 يبين معلم الأحياء التنظيم التركيبي والوظيفي في الخلية الحية.

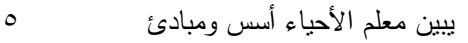
التتوع الحيوي، وتصنيف الكائنات

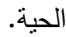

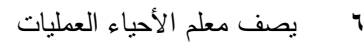
الحيوية التي تحدث داخل الكائنات الحية.

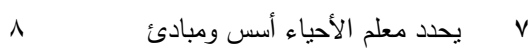
علم الوراثة في الكائنات الحية. يوضح معلم الأحياء أسس ومبادئ علم البيئة، والأنظمة البيئية، وسلوك الاحئ ومباد

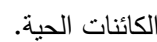

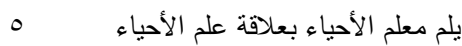

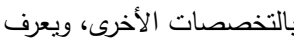
تطبيقات علم الأحياء والقضايا

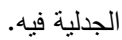

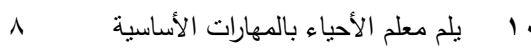
لمعلم الأحياء، والتوجهات الحديثة في التربية العلمية. 7 يلم معلم الأحياء بطرائق التدريس، 11 الخاصة في التربية العلمية.

و استخدم البـاحثان مقياس ليكـر ت الخماسـي لتمكين عينـة البـحث مـن تقييسـد آرائهـم عـن مستوى توافر كل فقـرة مــن فقـر ات الأداة

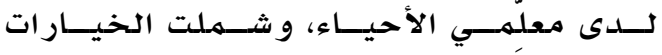

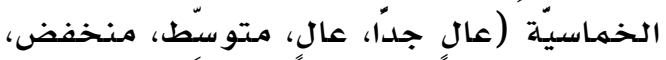
منخفض جداً). 
بين كل فقرة من الفقرات مـع المحور الذي

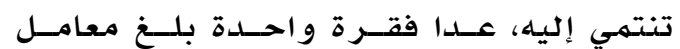

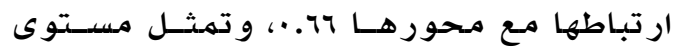

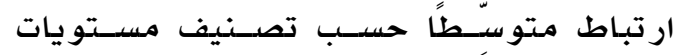

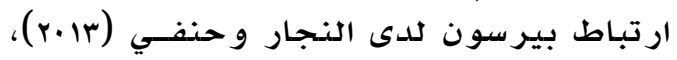

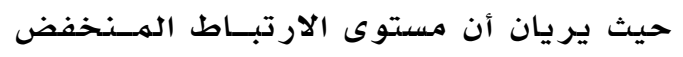

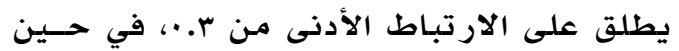

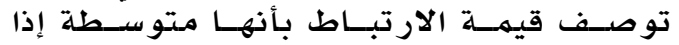

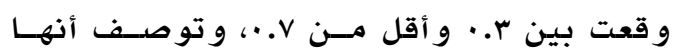

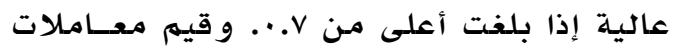

و الهـحور الذي تنتهي إليه، مـن خلال حســاب

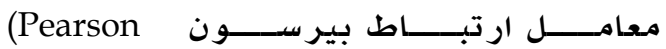
بين نتيجــة الفقـرة والمـحــور Correlation)

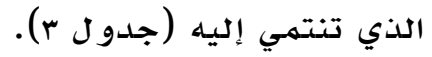
وتظهر نتائج الاتسـاق الداخلي فـي الجــدولr

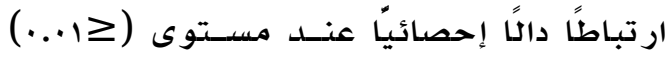

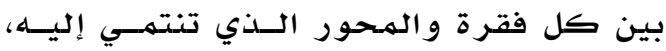

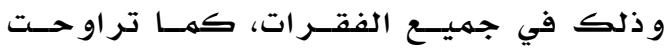

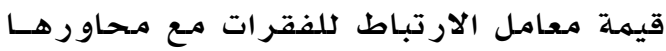
بين VY.Vr و •9.•، مـما يشير إلى ارتبـاط عـالٍ

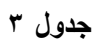

معاملات ارتباط بيرسون ومستوى دلالته بين كل فقرة والمحور الأي تنتمي إليه.

\begin{tabular}{|c|c|c|c|c|c|c|c|c|c|}
\hline \multicolumn{2}{|c|}{ المحور الخامس } & \multicolumn{2}{|c|}{ المحور الرابع } & \multicolumn{2}{|c|}{ المحور الثالث } & \multicolumn{2}{|c|}{ المحور الثاني } & \multicolumn{2}{|c|}{ المحور الأول } \\
\hline معامل & رقم الفقرة & معامل & رقم الفقرة & معامل & رقم الفقرة & معامل & رقم الفقرة & معامل & رقم \\
\hline الارتباط & & الارتباط & & الارتباط & & الارتباط & & الارتباط & الفقرة \\
\hline$" . \Delta r$ & rV & $" . . \wedge \mathrm{T}$ & ru & $" . . \vee \wedge$ & 10 & $" . V Y$ & $\wedge$ & ". . vo & 1 \\
\hline$" . \wedge V$ & rی & $" . . \wedge \Lambda$ & rr & $" . .10$ & 17 & $" . . \vee \wedge$ & 9 & $" . \vee \vee 9$ & r \\
\hline$" . .19$ & rq & $" . .10$ & r & $" . .11$ & iv & $" . . \wedge \varepsilon$ & 1. & $* . . v r$ & r \\
\hline$" . . \wedge \mathrm{V}$ & $r$. & $" . .10$ & $r \varepsilon$ & $" . .14$ & 11 & $* . .19$ & 11 & $* . \wedge$ & $\varepsilon$ \\
\hline$" . .10$ & m & $" .10$ & ro & $" . . \wedge \varepsilon$ & 19 & $" * .19$ & K & $" . . \vee \wedge$ & 。 \\
\hline-- & -- & $" . . \wedge V$ & ry & $* * . \wedge 1$ & $r$. & $* * . V \leq$ & r & $" . .74$ & 7 \\
\hline-- & -- & -- & -- & -- & -- & $" . v 4$ & $1 \varepsilon$ & $" . v r$ & v \\
\hline \multicolumn{2}{|c|}{ المحور العاشر } & \multicolumn{2}{|c|}{ المحور التاسع } & \multicolumn{2}{|c|}{ المحور الثامن } & \multicolumn{2}{|c|}{ المحور السابع } & \multicolumn{2}{|c|}{ المحور السادس } \\
\hline معامل & رقم الفقرة & معامل & رقم الفقرة & معامل & رقم الفقرة & معامل & رقم الفقرة & معامل & 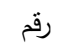 \\
\hline الارتباط & & الارتباط & & الارتباط & & الارتباط & & الارتباط & الفقرة \\
\hline$" . \wedge r$ & 00 & $" . \wedge 1$ & 0. & $" . . \wedge 7$ & $\varepsilon \varepsilon$ & $" . \wedge 1$ & T & $" . . \wedge \varepsilon$ & re \\
\hline$" . \Delta r$ & 07 & $" . .10$ & 01 & $\because . \wedge \wedge$ & 纟o & $" . \wedge$ & rv & $" . . \wedge V$ & זr \\
\hline ". & ov & $" * . \wedge \Lambda$ & or & $* * \wedge \wedge$ & $\varepsilon 7$ & $" . . \wedge V$ & ץ & $" . . \wedge V$ & $r \varepsilon$ \\
\hline$" . .11$ & 01 & $* * . \wedge$ & or & $" . \wedge \mathrm{V}$ & $\varepsilon V$ & $" . .19$ & rq & $" . . \wedge 9$ & ro \\
\hline$" . A r$ & 09 & $* .10$ & $0 \leqslant$ & $" . .17$ & $\leqslant \wedge$ & $* .9$ & $\varepsilon$. & -- & -- \\
\hline$" . .10$ & 7. & -- & -- & $* * .11$ & $\leqslant 9$ & $* . . \wedge V$ & $\varepsilon 1$ & -- & -- \\
\hline$\because . \wedge V$ & $\pi$ & -- & -- & -- & -- & $" . \wedge \Lambda$ & $\varepsilon r$ & -- & -- \\
\hline \multirow[t]{6}{*}{$" . . \wedge 1$} & Tr & -- & -- & -- & -- & $" . \wedge$ & $\varepsilon r$ & -- & -- \\
\hline & & & \multicolumn{7}{|c|}{ المحور الحادي عشر } \\
\hline & & & & معامل & رقم الفقرة & معامل & رقم الفقرة & معامل & رقم \\
\hline & & & & الارتباط & & الارتباط & & الارتباط & الفقرة \\
\hline & & & & $" . . \wedge \mathrm{V}$ & TV & $" . \wedge V$ & 70 & $" . \wedge \Lambda$ & זי \\
\hline & & & & $" * . \wedge 7$ & 71 & $" . . \wedge \Lambda$ & 77 & $*$ & $7 \varepsilon$ \\
\hline
\end{tabular}


التّعليهم؛ للحصول على دعمــه لتطبيـق الأداة،

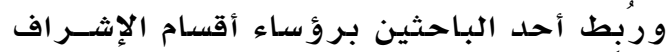

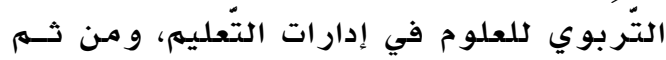

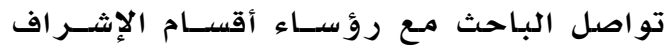

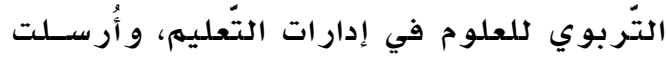

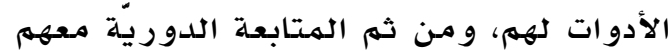

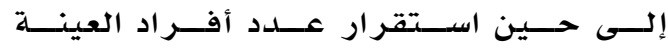

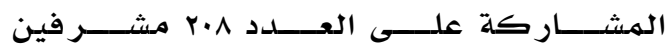
و مشر فات. المعالجة الإحصائية وتفسير البيانات استُخدمت في هذا البـحث أسـاليب المعالجـة الإحصائيّة التَّالية:

التّكر ارات و النسبب المئويَّة: لعـر ض

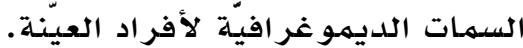
الهتوسِط الحسابِيٌ: لتحديد مستوى

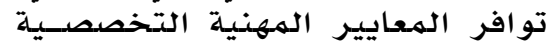

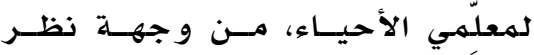

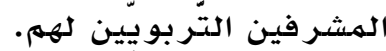

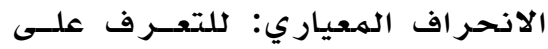

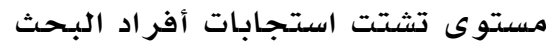
كل محورٍ عن متوسطها الحسابي.

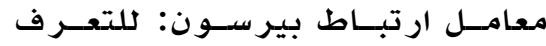
على مستوى الاتســاق الـــاخلي مــن مئن

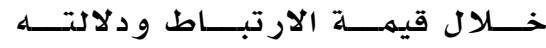
الإحصائيةّ، بين كل فقرة في الأداة و محوررها الذي تنتهـي إليه. معامل ألفا كرو نباخ: للتحقــق مــن مستوى ثبات الأداة، و محاور هـا. اختبـــار (ت) لعينتـــــن مســـتلتين: للتعرف على دلالة الفروق بين آراء

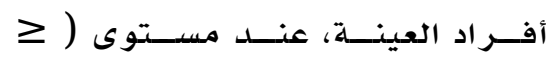

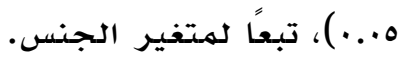
واسـتخدلدم البـحسث الحسـالي مقيــاس ليكـر ت

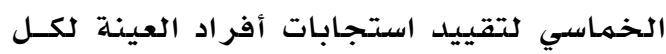

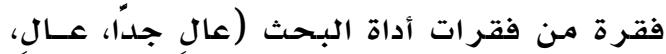

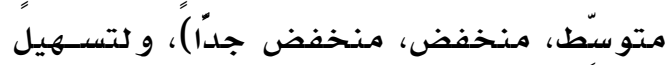
عــر ض البيانــات و تفســير ها قـــام البـاحثــان
الارتباط ودلالتهــا الإحصـائيّة بــين الفقـرة

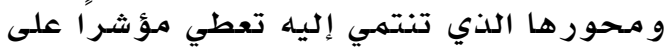

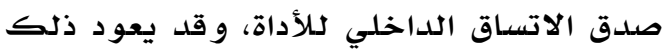

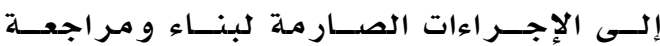

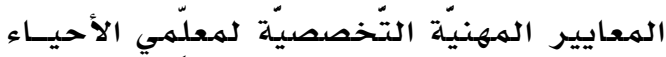

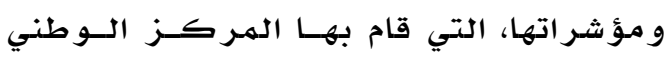

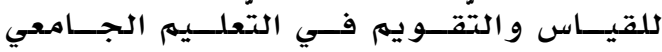

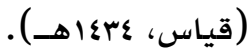
ثبات أداة الدراسة

تم قياس معامل ألفا كرونباخ (Cronbach's تماخ Alpha) للتعرف فلى مستوى ثبات الأداة ومححاور رهـا،

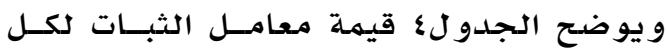
محور من الهحاور، و لكلأداة بشكل كامل.

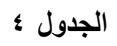

معامل ألفا كرونباخ لثبات محاور الأداة

\begin{tabular}{|c|c|c|}
\hline معامل ألفا كرونباخ & عدد الفقرات & المحاور \\
\hline..$\wedge V$ & v & الأول \\
\hline$\therefore 9$. & v & ال الثاني \\
\hline .91 & 7 & الثالث الث \\
\hline r.9 & 7 & الرابع \\
\hline .91 & 。 & الخامس \\
\hline. .19 & $\varepsilon$ & السادس \\
\hline .90 & $\wedge$ & السابع ل \\
\hline .94 & 7 & ال الثامن \\
\hline .91 & 0 & التاسع \\
\hline $.9 \leq$ & $\wedge$ & العاشر \\
\hline $.9 \leq$ & 7 & الحادي عشر \\
\hline. .91 & 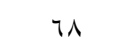 & الأداة كاملة \\
\hline
\end{tabular}

و تر اوحست قــيهم معامــل ألفــا كرونبــاخ

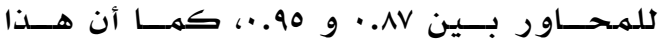

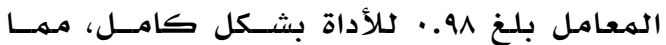

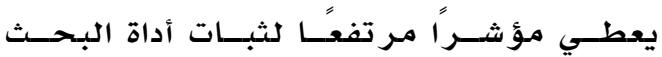

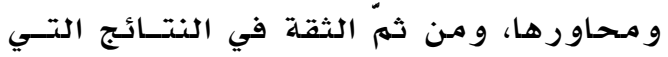
يتهم جمعها مـن خلاولها، ومن لها. إجراءات تطبيق الدراسة تم تطبيق أداة البحث بعـد اسـتكمال بنـائهـا، و أخذ الموافقات الرسميّة للتطبيق من خلافل المان تواصل أحد الباحثين مـع مشرف الأحياء فــي

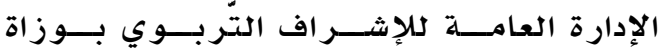




\section{نتائج الدر اسة ومناقشتها}

السؤال الأول: ما مســتوى تــوافر المعـايير

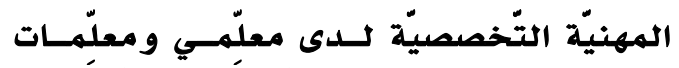

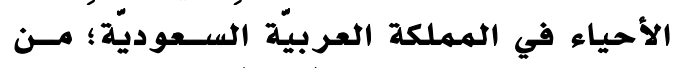

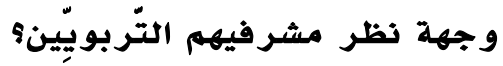

تمت الإجابة عن هذا السؤال من خلال عرض

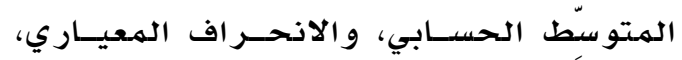

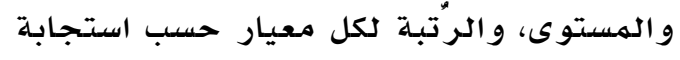

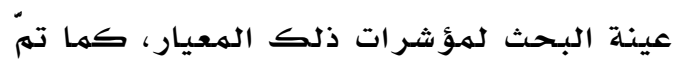

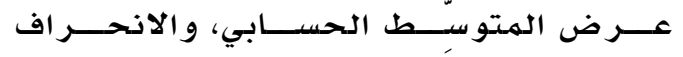

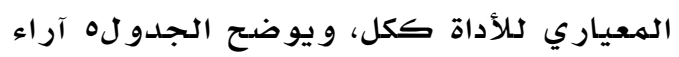

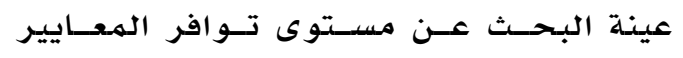

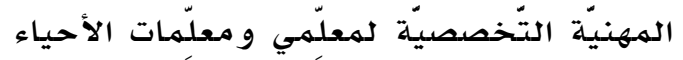

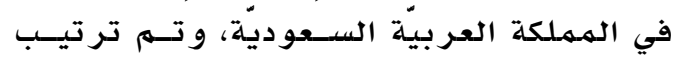

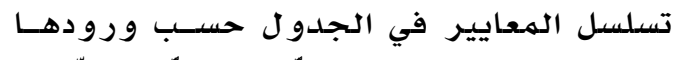

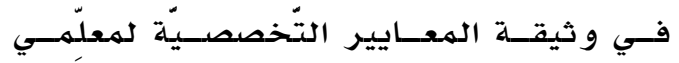
الأحياء.
بتحديد خمسـة مسـتويات للحُكسم علـى آراء

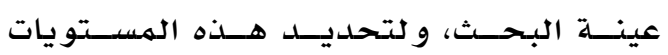

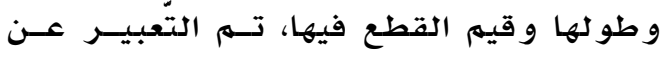
المستوى الأعلى في أداة البحث (عسالٍ جـــاً)

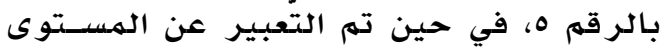

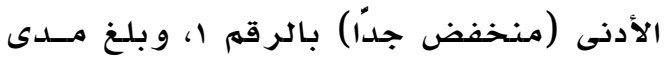

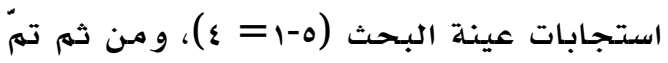

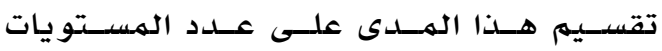
المقترحة (خمسـة مستويات)، ليكون مقــــار

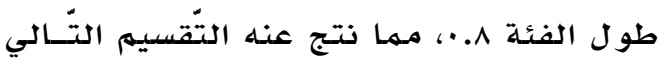

$$
\text { ل ل لمستو يات: }
$$

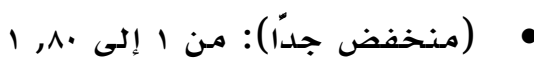

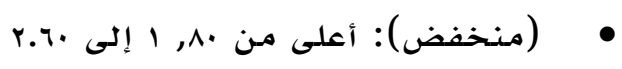

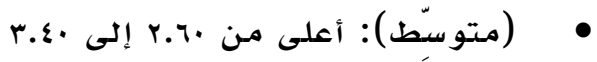

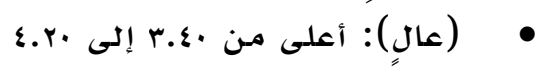

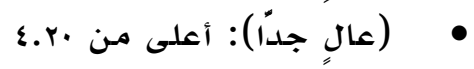

جدول

\begin{tabular}{|c|c|c|c|c|c|}
\hline التزتيب & 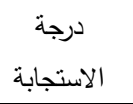 & 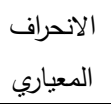 & الحسابي & 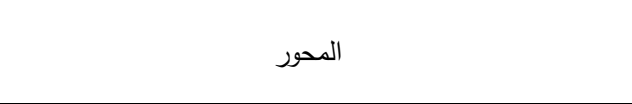 & r \\
\hline v & عال & ז & r.01 & يعرف معلم الأحياء طبيعة علم الأحياء وتاريخ تطوره. & 1 \\
\hline 11 & 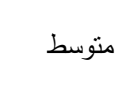 & $\therefore$ vo & r... & 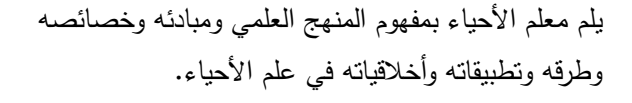 & r \\
\hline 1 & عال & $\cdot \wedge$. & r.ov & والأمان في المختبر . & $r$ \\
\hline 1 & 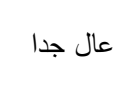 & .71 & $\varepsilon . \varepsilon \varepsilon$ & الحيية. معلم الأحياء التظظيم التركيبي والوظيفي في الخلية & $\varepsilon$ \\
\hline r & 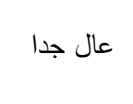 & rT & E.rt & الكيائنات الحية. & 。 \\
\hline r & 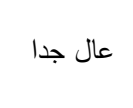 & rT & ז.r & الكائنات الحعة. الأحياء العمليات الحيوية التي تحدث داخل & 7 \\
\hline$\circ$ & عال &..$v v$ & r.qv & يحية. معلم الأحياء أسس ومبادئ علم الوراثة في الكائنات & v \\
\hline$\varepsilon$ & عال & $.7 \uparrow$ & $\{.17$ & وسلوك الكائنات الحية. & $\wedge$ \\
\hline$\wedge$ & 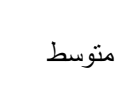 &..$\wedge r$ & r.r. & ويعرف تطبيقات علم الأحياء والقضاياء الجدلية فيه. & 9 \\
\hline 9 & 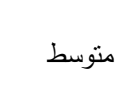 & $\because \vee \vee q$ & r.Ir & والتمجهات الحديثة في التربية العلمية. & 1. \\
\hline 1. & 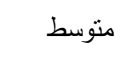 & .91 & r.ı. & يلم معلم الأحياء بطرائق التنريس الخاصة في التربية العلمية. & 11 \\
\hline- & عال &. $.0 \mathrm{~V}$ & r.Vt & بط العام لمحاور البحث ككل & \\
\hline
\end{tabular}


و أربعة معايير بمستوى عال، و أربعة معـايير بمستوى متوسطٍ لدى معلبمي الأحيـاء، كهـا

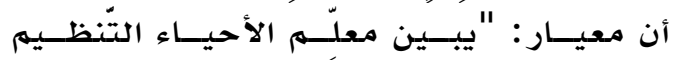

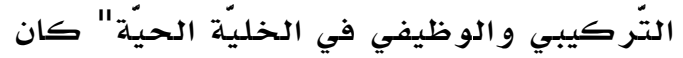

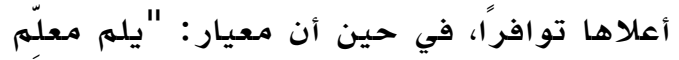

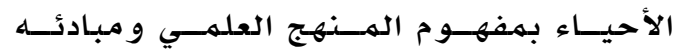
و خصائصده وطرقه و تطبيقاته و أخلاقياته في له

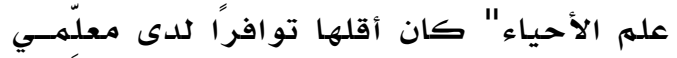
الأحياء.

و ترو احست قـيم الانحسـر اف المعيــاريِّ لآراء العينة حول مستوى توافر المعايير الههنيــة

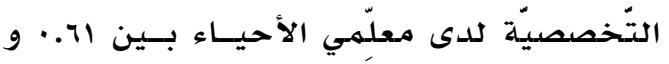

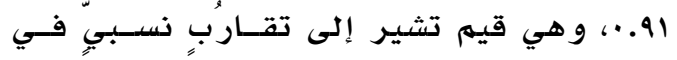
آراء العينـة حول تحديد مستوى تـوافر هــــه

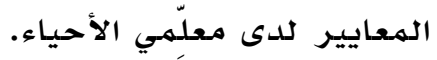

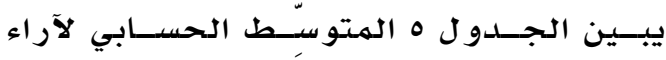

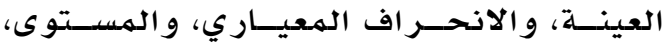

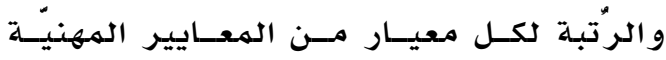

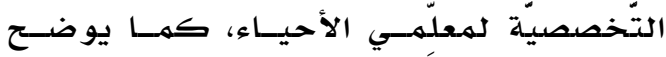
الجدول الهتوسط العام لآراء العينة،

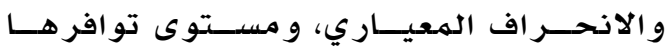

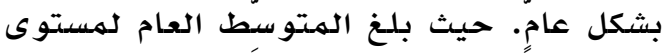

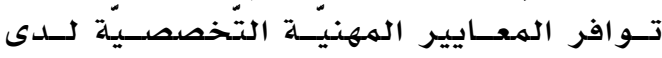
معلِّمي الأحياء مــن وجهــة نظــر مشــرفيهم

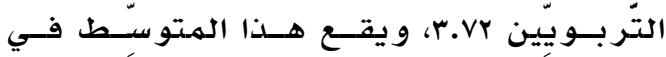

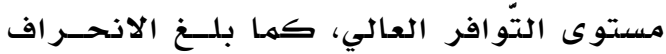
المعياري OV.OV، و هي قيهمة تشير إلـى تقـارب

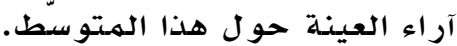
كما يبين الجدول ه أن عينـة البحسث تـرى

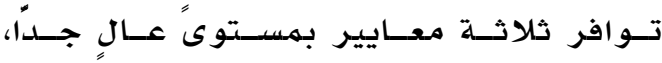

جدول 7

نتائج اختبار (ت) للعينات المستقلة بين آراء عينة البحث حول مستوى توافز المعايير المهنية التخصصية لاى معلمي الأحياء

تبعا لمتغير الجنس

\begin{tabular}{|c|c|c|c|c|c|}
\hline 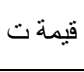 & الانحرياري & 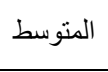 & العدد & 5 & 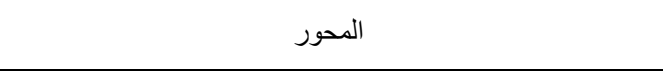 \\
\hline \multirow{2}{*}{$\because$ vo } & $\because 7$ & $r .0$. & $9 \mathrm{YV}$ & ذأنكر & يعرف معلم الأحياء طبيعة علم الأحياء وتاريخ تطوره \\
\hline & $\because 7 \mathrm{~V}$ & 7.7. & 89 & 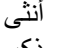 & \\
\hline \multirow[t]{2}{*}{$*^{*} r_{1}$} & $\cdot v$ & $.4 \mathrm{~V}$ & $4 V$ & دكر & يلم معلم الأحياء بمفهوم المنهج العلمي ومبادئه وخصائصده وطرقه \\
\hline & $\because \vee \wedge$ & r.r & vq & أنثى & وتطبيقاته وأخلاقياته في علم الأحياء \\
\hline \multirow[t]{2}{*}{ *tr } & $\because \wedge r$ & r. $\varepsilon 0$ & $9 \vee$ & ذ ذكر & يجري معلم الأحياء التجارب العلمية مراعيا قواعد السلامة والأمان \\
\hline & 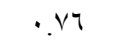 & $r . v 1$ & va & أنثى & في المختبر \\
\hline${ }^{*}$ r.०. & .04 & 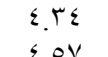 & $9 \vee$ & 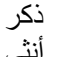 & يبين معلم الأحياء التتظيم التزكيبي والوظيفي في الخلية الحية. \\
\hline \multirow{2}{*}{1.0} & .70 & $\varepsilon . Y \uparrow$ & $9 \vee$ & 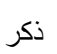 & يبين معلم الأحياء أسس ومبادئ التنوع الحيوي وتصنيف الكائنات \\
\hline & $\cdot .71$ & «. & va & أنثى & 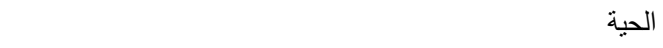 \\
\hline \multirow{2}{*}{$*$ r.01 } & .70 & $\varepsilon$ & $9 \vee$ & ذكر & يصف معلم الأحياء العمليات الحيوية التي تحدث داخل الكائنات \\
\hline &. .07 & $\varepsilon . \leqslant 7$ & v9 & أنثى & 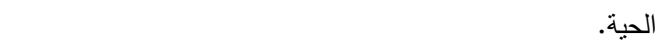 \\
\hline 1.7 & $\because v \varepsilon$ & $r . \wedge 9$ & $9 \vee$ & ذأكر & يحدد معلم الأحياء أسس ومبادئ علم الوراثة في الكائنات الحية. \\
\hline \multirow{3}{*}{$*_{r}^{t}$} & $\because v 9$ & $\begin{array}{ll}\varepsilon \cdot V \\
\varepsilon .7\end{array}$ & $\begin{array}{l}\text { Vq } \\
9 y\end{array}$ & 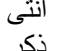 & \\
\hline & $7 y$ & 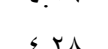 & . & ה" הر & يوضح معلم الاحياء اسس ومبادئ علم البيئه والانظمه البيئية \\
\hline & . & r & . & (1) & وسلوك الكائنات \\
\hline \multirow{2}{*}{$\cdot .99$} & $\because \mathrm{VA}$ & $T . T V$ & $4 V$ & دكر & يلم معلم الأحياء بعلاقة علم الأحياء بالتخصصات الأخرى، ويعرف \\
\hline & $\because \wedge \Lambda$ & re & $v 9$ & أنثى & تطبيقات علم الأحياء والقضايا الجدلية فيه. \\
\hline \multirow[t]{2}{*}{1.11} & $\because \vee 9$ & $r . r$ & $9 \vee$ & ذ ذكر & يلم معلم الأحباء بالمهارات الأساسية لمعلم الأحياء والتوجهات \\
\hline & $\cdot 17$ & $r . r \leq$ & vq & أنثى & الحديثة في التربية العلمية \\
\hline$*^{*} .01$ & $\begin{array}{l}\because 9 r \\
. \Delta r\end{array}$ & 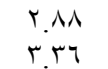 & $\begin{array}{l}9 V \\
V q\end{array}$ & ذأنثر & \multirow{3}{*}{ المنوسط العام } \\
\hline \multirow{2}{*}{ *r.or } & $.0 \mathrm{~V}$ & r.T & $9 \vee$ & ذكر & \\
\hline &. .00 & r.A $\varepsilon$ & vq & أنثى & \\
\hline
\end{tabular}




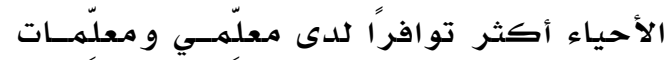

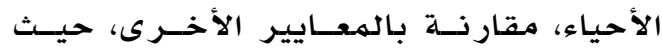

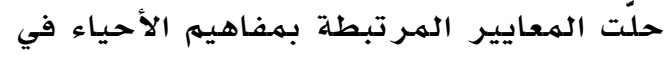

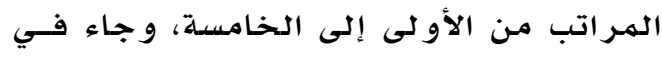

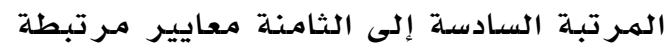

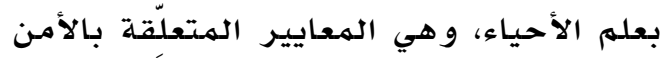

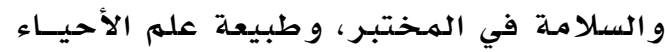

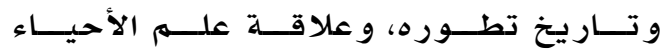
بالتّخصصات الأخرى، و تطبيقات عله الأحياء

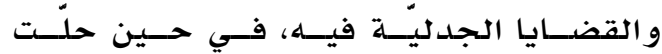

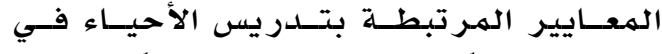
المر تبتين التًاسعة والعاشرة، وحسل" المــهـج

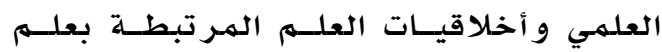
الأحياء في المرتبة الحادية عشرة.

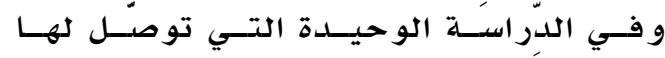

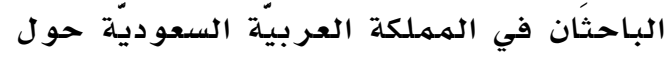

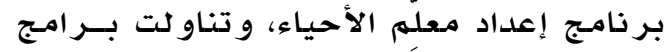

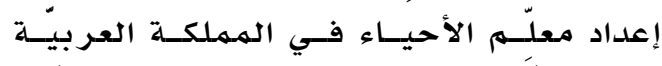

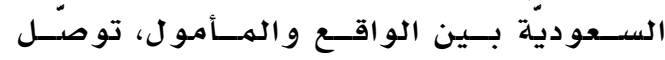

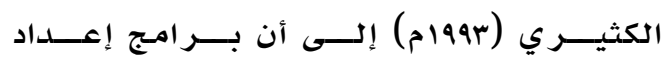

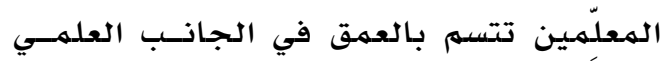

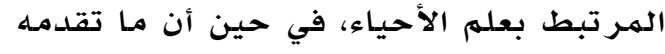

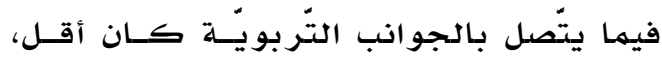

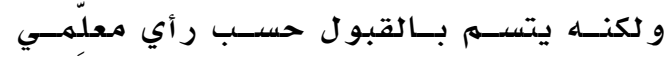

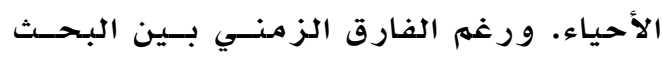

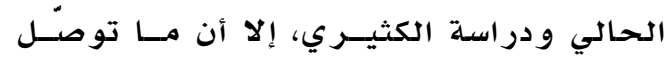

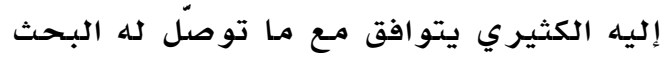

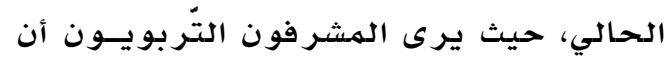

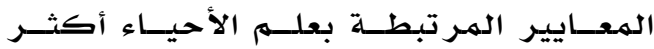

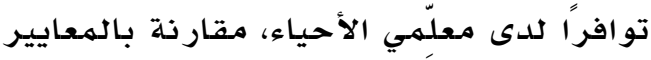

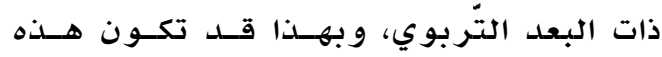

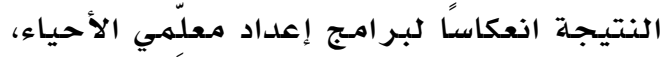

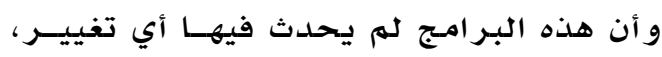

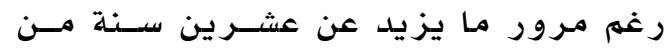
إجراء دراسة الكثيري. وتؤكد نتائج دراسة

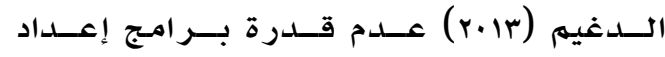

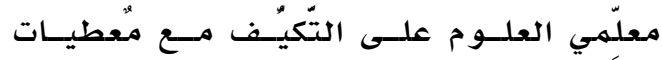

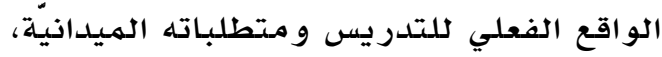
مما يعزّز فرضيّة ضعف تطوير بر امهج إعداد
السؤال الثاني: هل توجد فروق ذات دلالــة

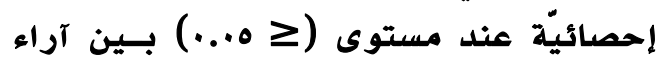

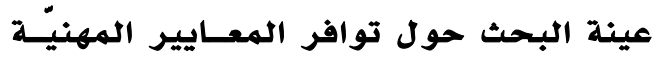

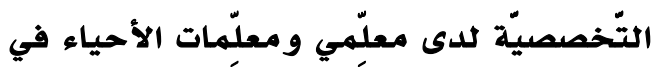

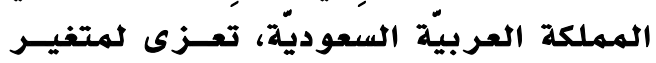

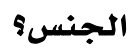

يوضتح الجدول 1 نتائج اختبار (ت) للعينات

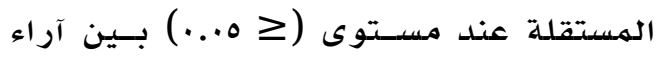

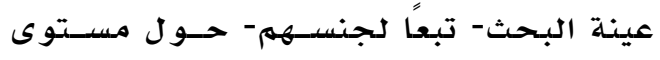

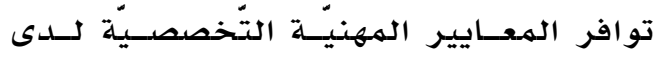
معلّمِي الأحياء.

و تظهر النتائج في الجدول ل وجـــود فــروق

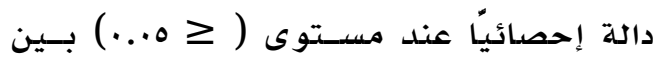

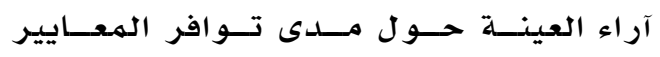

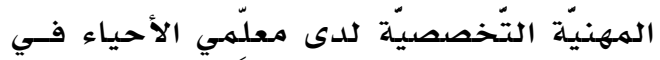

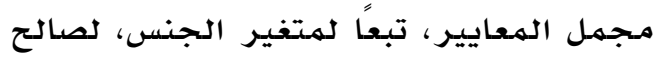

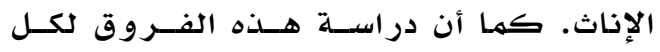

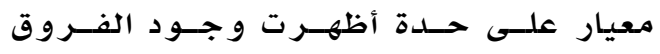
الدالة إحصائيًا عند مستوى (

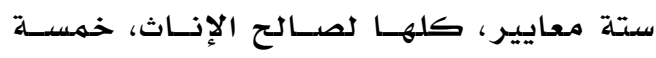

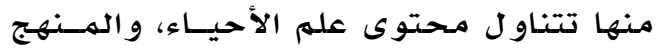

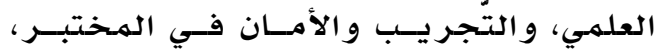

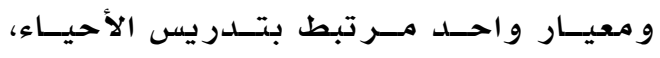

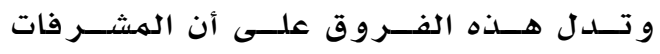

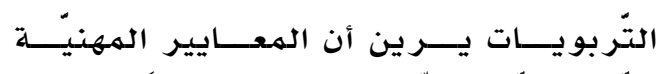

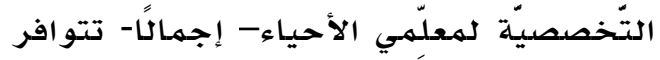

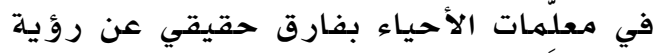

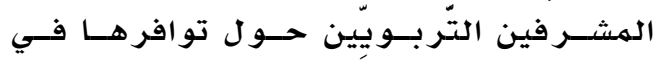

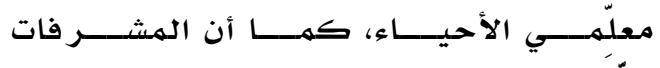
التَربويات يرين توافر ستة معايير - حسبس الآداء

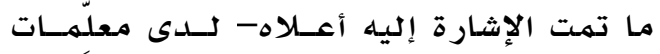

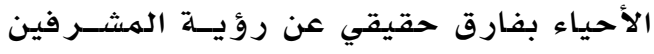

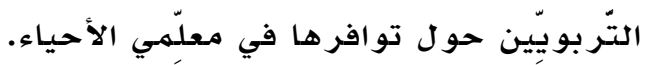

\section{مناقشة النتائج}

أظهرت نتائج مقار نة متوسِّــات آراء عينــة البحث حول مستوى توافر المعايير المهنية

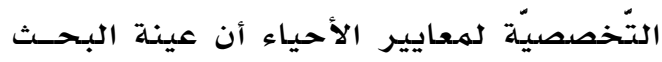

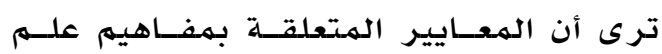




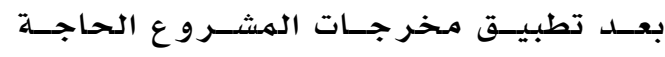

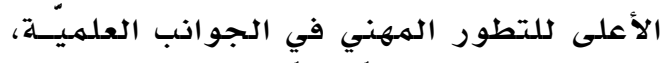

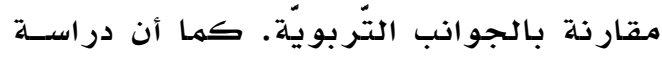

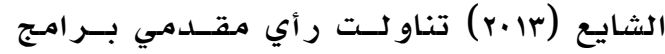

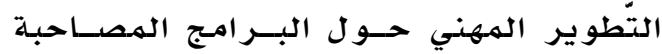

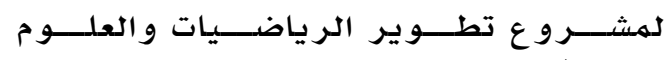

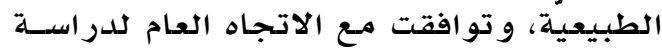

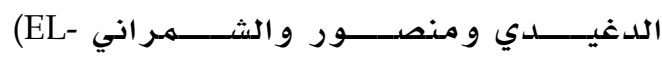
،Deghaidy, Mansour, \& Alshamrani, 2014)

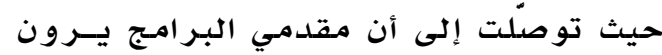

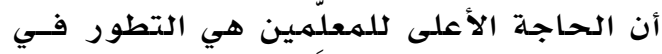

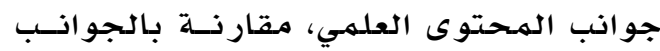
التّر بويَّة.

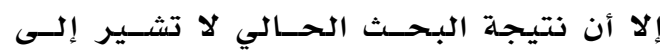

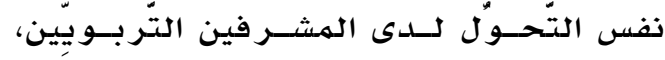

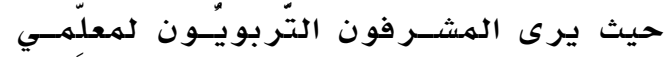

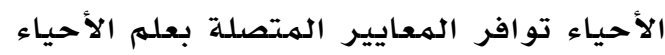

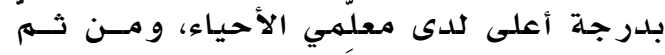

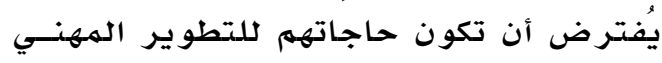

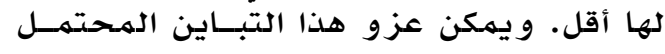

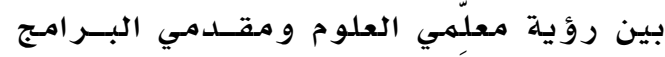

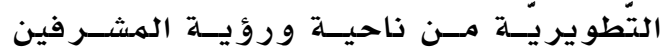

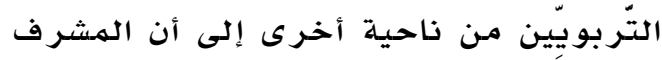

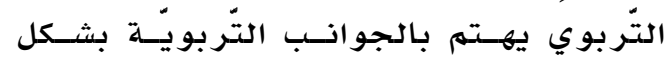

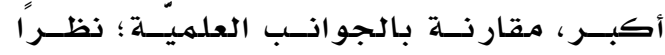
كلأدوار و المههام التي يقوم بها، و التي يعكسها

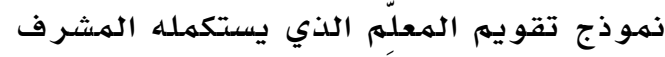

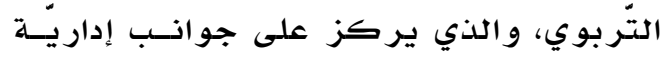

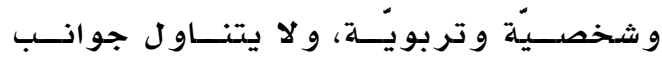

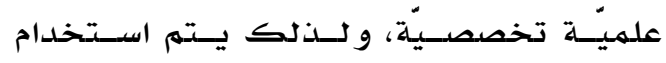

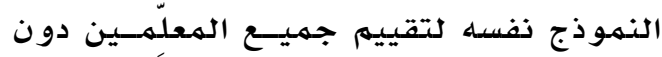
مر اعاة تباين تخصصاتهم (القر يشي، .... (ب). و يفســر منصـــور و الشـــــر اني و الــــهمش

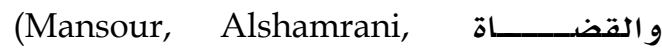
Aldahmash, \& Alqudah, 2013)

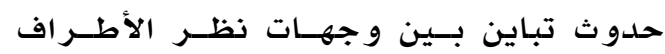

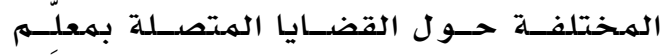
العلوم، من خلال تأكيد أن كل طرف مـن

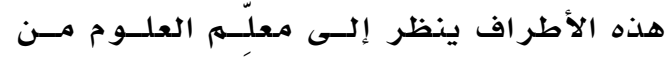

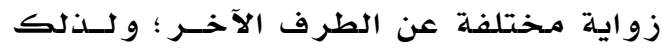

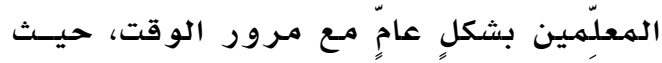

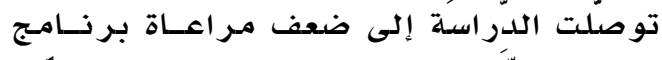

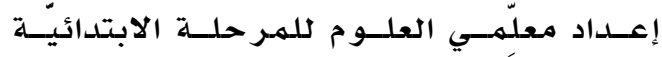

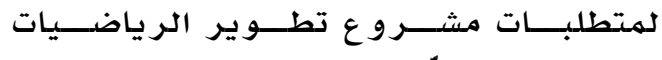

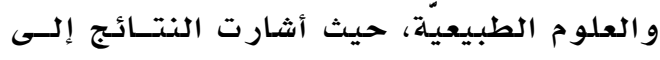

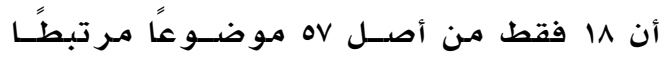

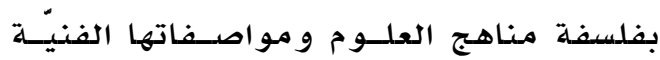

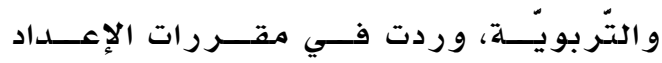

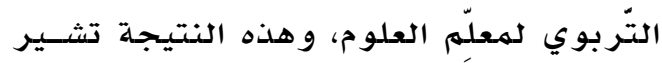

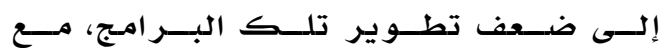
استحداث مشروع تطوير الرياضيات و العلوم الطبيعيَة.

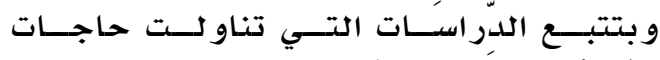

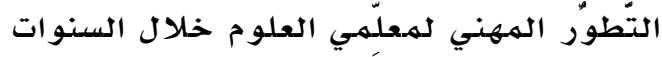

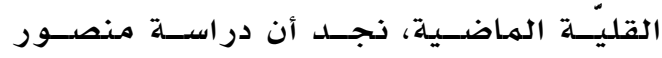

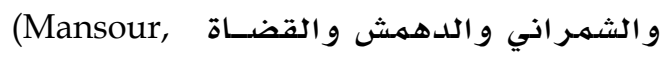
Alshamrani, Aldahmash, \& Alqudah, (2013)

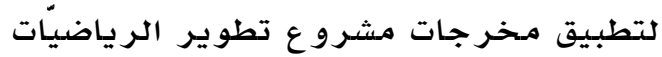

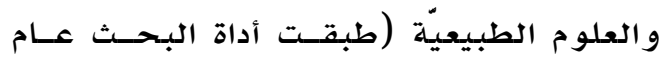

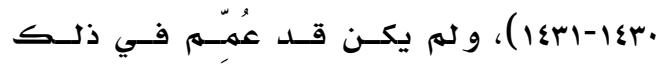

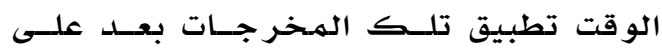

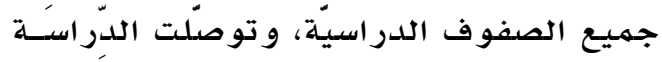

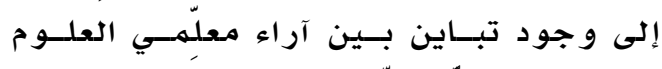

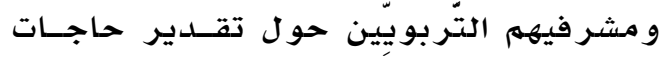

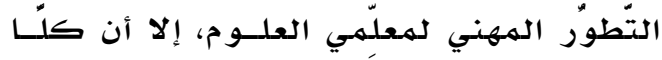

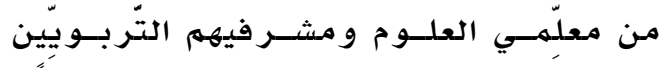

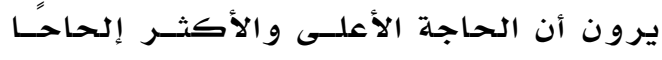

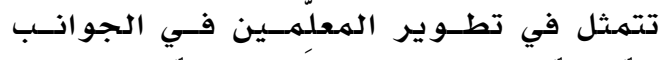

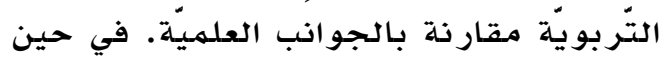

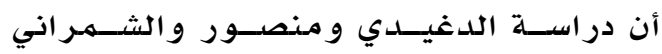
(EL-Deghaidy, Mansour, \& Alshamrani, مخر (2014 - التـي طبقـت بعـد تعمــيهم تطبيـق

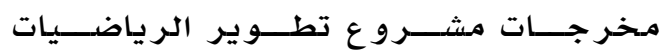

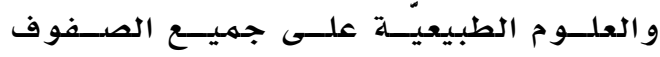

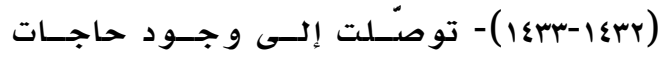

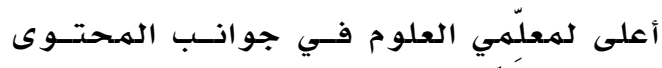

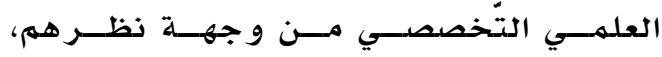

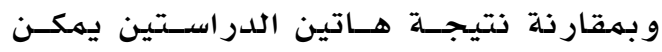

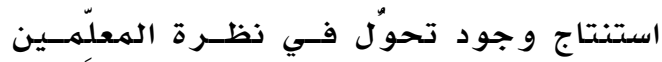

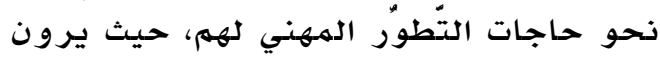




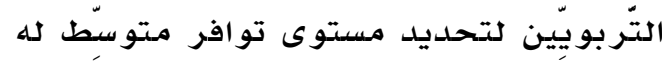
لدى معلّهمي الأحياء.

و من اللافت في نتائج البحث الحالي حصول

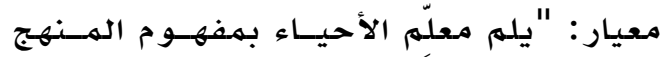

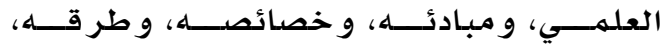

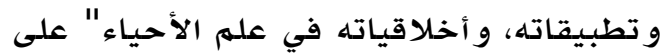

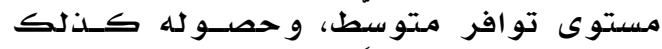

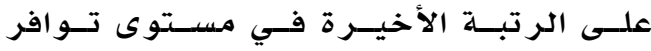

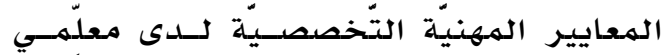

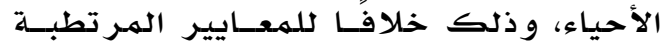

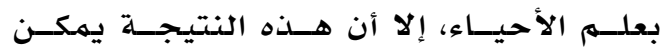
تفسير ها بما توصَّلت لـهـ دراســة الحصــان،

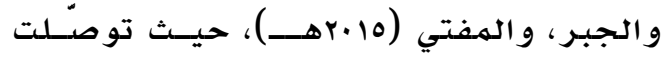

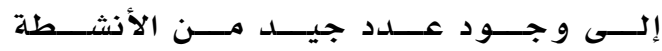
الاستقصائية فـي كتــب الأحيـاء للمـرحلــة

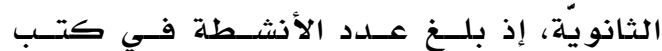

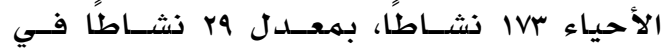

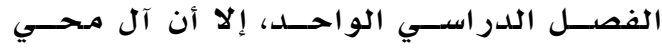

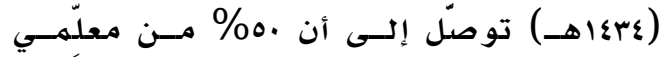

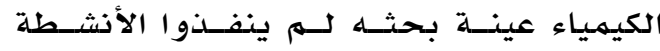

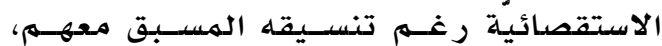

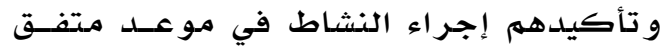

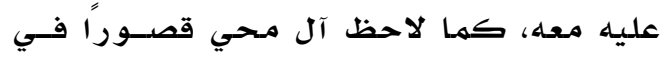

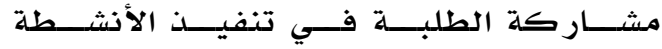

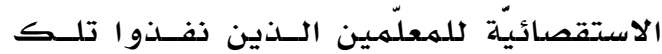

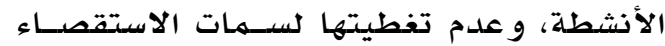

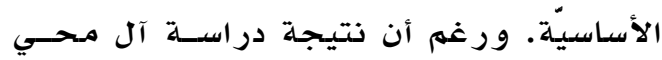

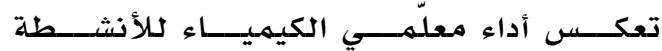

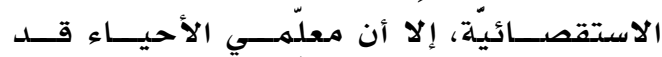
يمارسون الأنشطة بنفس المســتوى لتطـابق القابق

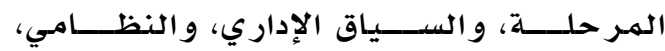

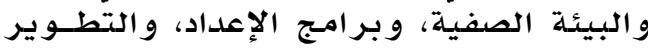

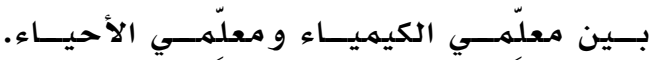

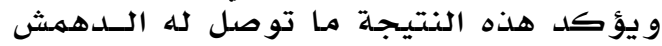

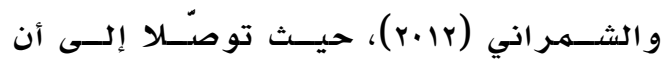

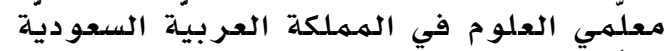

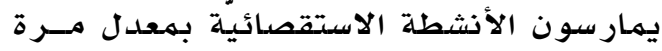

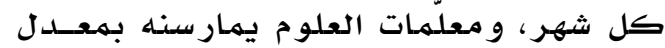

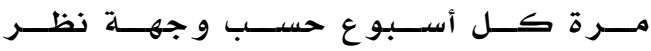

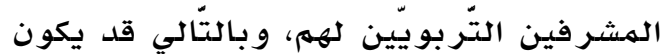

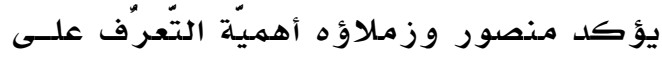

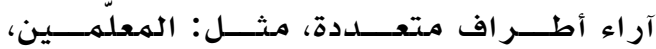

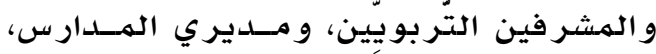

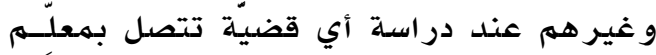

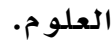

وفيما يتعلق بحصول معيارين آخرين غيـر

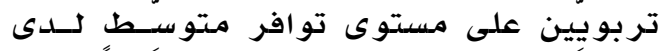

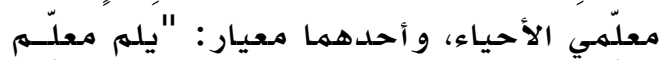

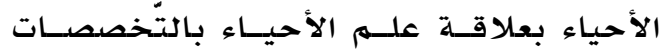

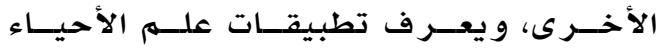

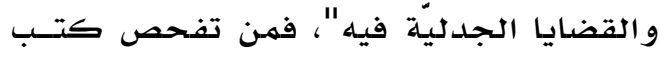
الأحياء في الهـرحلة الثانوية يمكن اسـتنتاج

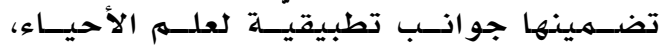

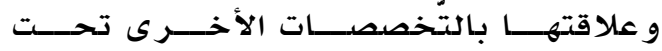

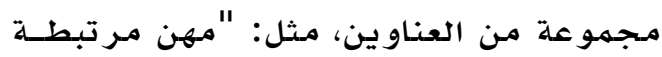

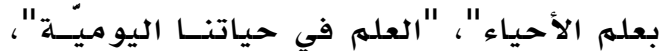

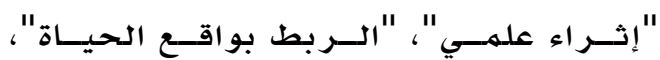

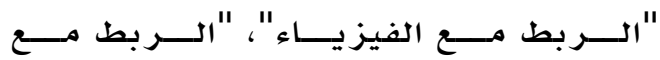

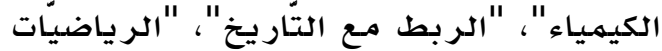

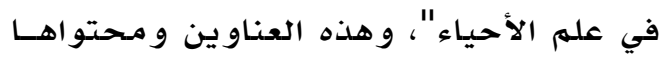

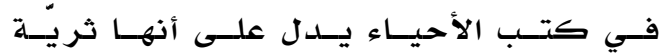
بالإثشارات التي تربط عله الأحياء بغيره من التخخصصات، وكذلك بتطبيقات علهم الأحياء

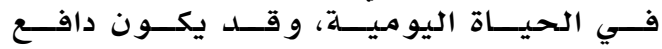

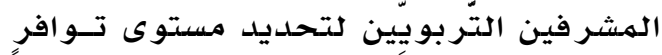

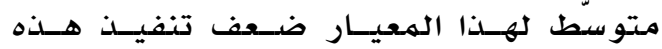

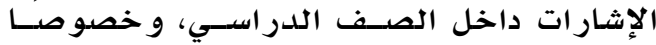

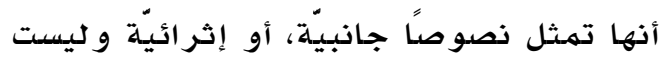

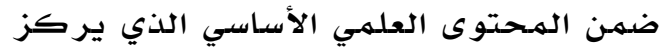

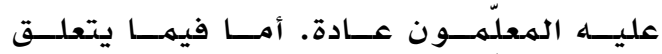

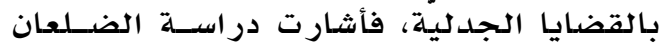

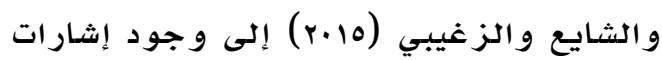

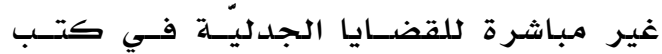

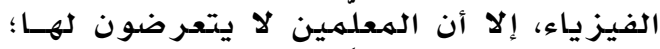

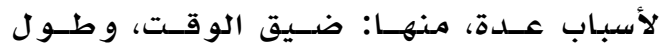

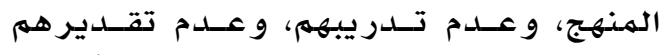
لأهميتها، و هذه النتيجة قد تنطبق أيضًا على

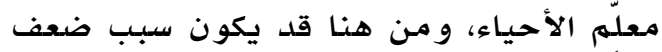

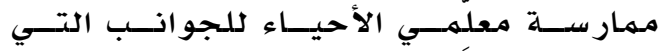

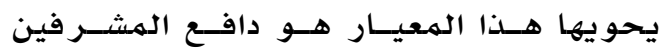


دال" إحصدـائيًا بــين آراء المشــرفين- تبعَّا

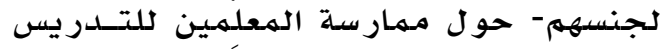

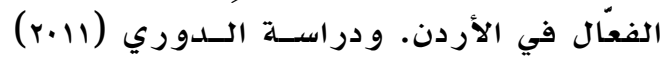
التي توصلت إلى وجـود فــرق دالٍ إحصــائيًا

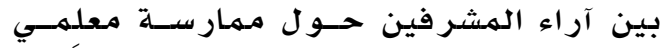

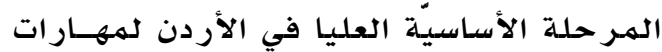

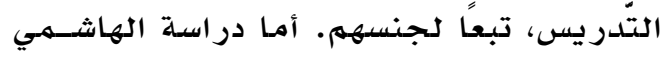

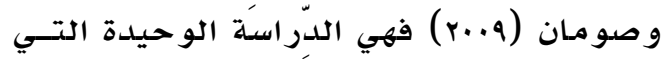

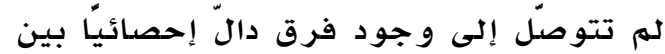

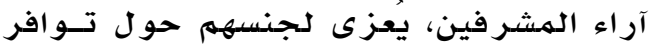

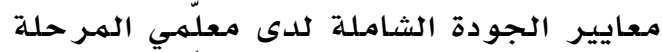
الثانوية في الأردن.

و بناء عليهـ؛ فإن الفروق التـي توصتّل إليهـا

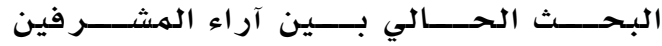

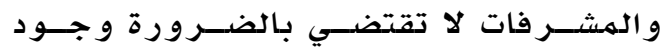
فروق حقيقية بين معلّمِي وومعلّمَات الأحيـاء

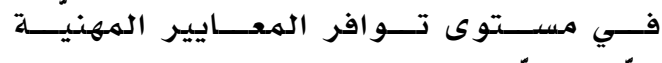

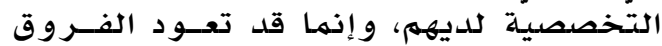
بين آراء المشرفين و المشر فات إلى عو امـل

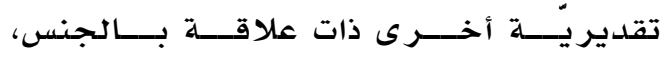
وخصوصًا في مثل مجتهـع المملكة العربيّة

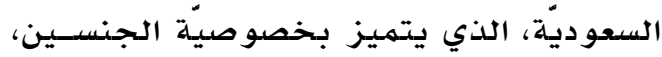

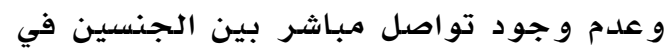

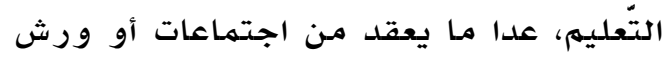

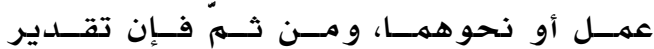

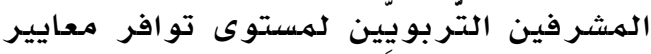

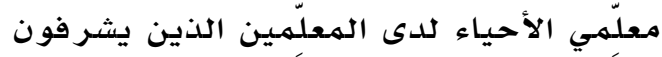

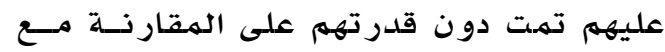

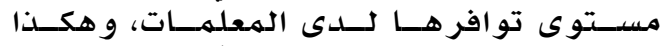
بالنسبـة للمشرفات التّربوبات، كمها أن توافق

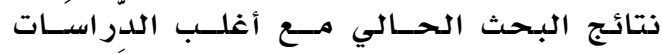

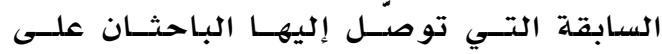

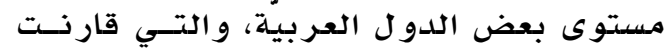
بين آراء المشرفين و المشرفات حول امتالكك

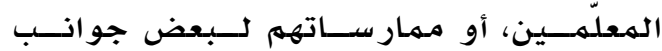
التّدريس يمكن أن يشير إلــى وجهـود اتجـــاه

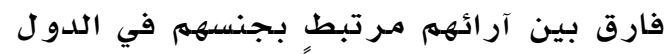
العربية، في ظل السياق الثقافي والاجتهماعي

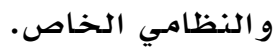

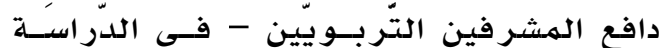
الحاليّة - لتحديد مستوى توافر معيار "يلم

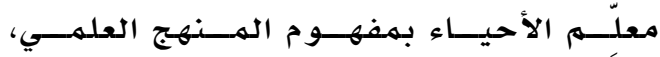
و مبادئه، و خصدائصسـه، و طرقــه، و تطبيقاتـه،

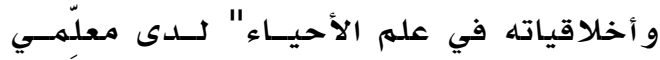

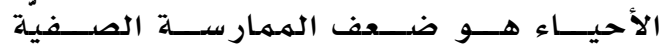

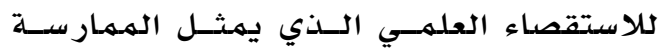

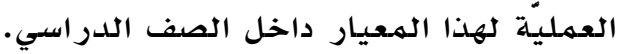
و فيمـــا يتعلــق بلدراســة الفـروق بـين آراء المشر فين و المشر فات حول مســتوى تـو افر المعايير المهنيّة التّخصصيّة لمعلّمهي الأحياء

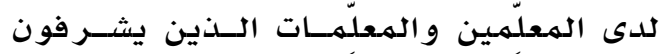

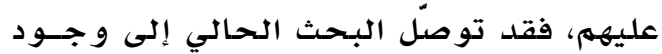

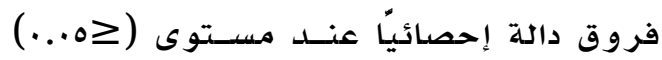

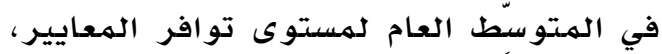
و فـي سـتة مسن المعـايير ، و كلهـا لصـالح

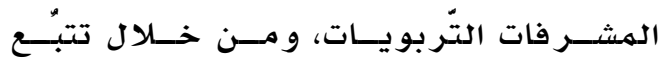

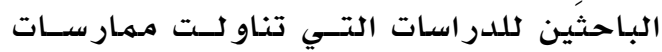

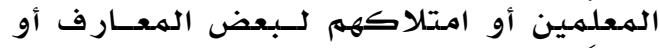

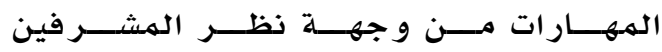

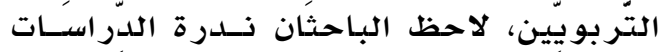

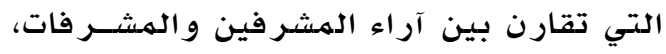

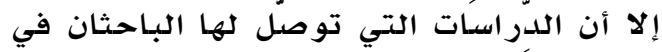
الوطن العربي- مـن خلال البـحث فـي قاعـدة

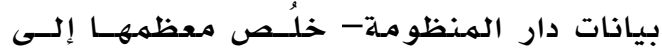

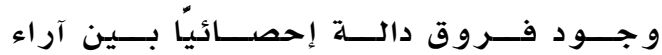

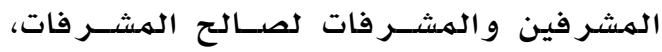

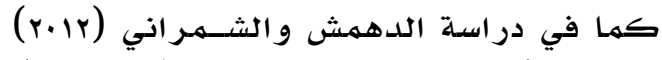
التي توصلت إلى وجـود فـرق دالٍ إحصــائيًا

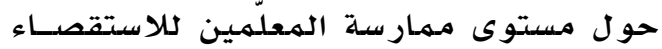

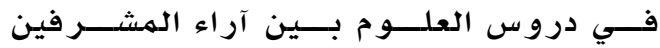

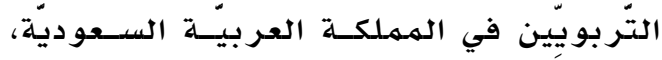

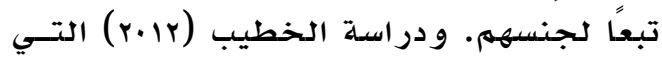
توصلت إلى وجود فـرق دالٍ إحصـائيًا بـين

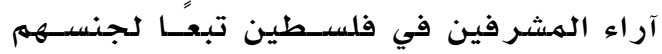

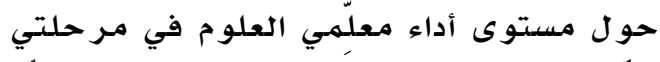

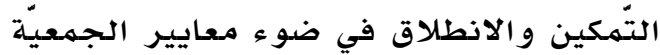
الأمريكية لمعلّهي العلوم National Science) Teacher Association NSTA) العمر ات (11) التي توصلت إلى وجود فرق ودراس 


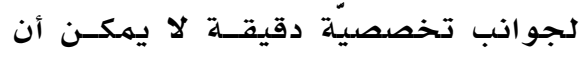
يلهم بها إلاّ متخصص في في علم الأحياء. كما يقترح الباحثان إجراء البحوث التًّليّة: ا. آراء معلّمي الأحياء أنفسه في مسلى

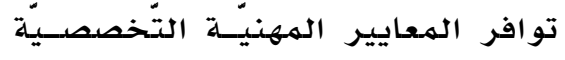

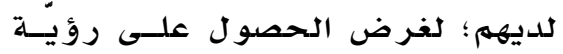

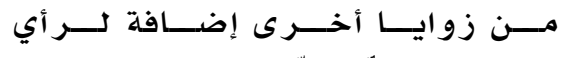
المشر فين التَر بويّين.

r. أسباب حصول بعض المعـايير علسى توافر متوسّط لدى معلّمسي الأحيـاء؛ لمعالجة هذه الأسباب إن أمكن. r. تحليل برامج إعـداد معلّمسـي الأحيـاء قبل الخدمة، و تطويرهم في أثنائهـا،

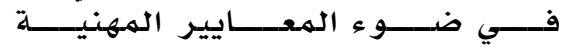

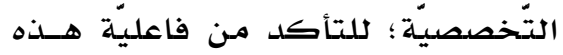
البرامج في تعزيز امتلاك المعلّمسين

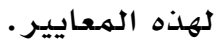

ع.دور جنس المشرفين في الحكم علـى

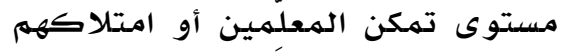
لبعض المهارات أو المعارف، في ظــل السياق الثقافي والاجتماعي و النظامي النهاري

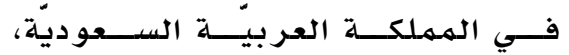

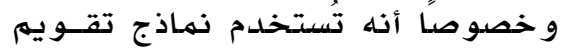
مشتركة للمعلّمين و المعلّمات.

المراجع

\section{References}

آل محي، سعيد (عاعاهـ). تضمين مهـارات

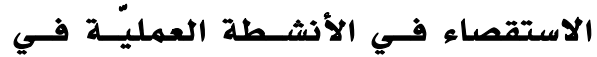
مقرر الكيميـاء للصــف الأول الثــانوي الأهيـ وواقع ممارسة الطـلاب إياهـا. رسـالة

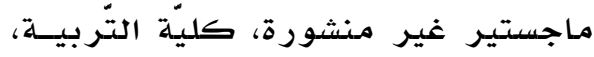
جامعة الملك سعود، السعوديّة.

الأمانة العامـة لجامعة الدول العربية

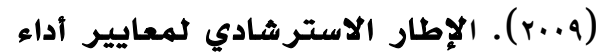

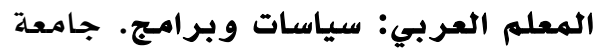

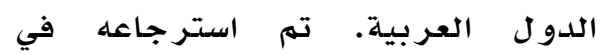
|
توصيات ومقترحات الدراسة

في ظلِّ نتائج البحث الحالي، يوصي البـاحثان

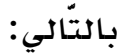
1. استخدام ذتائج البحث الحالي كمؤشر

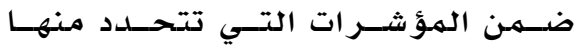

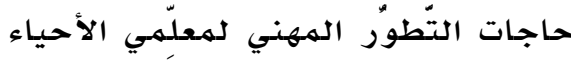

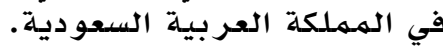

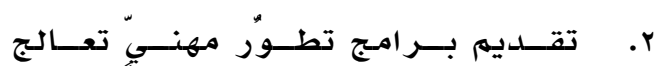

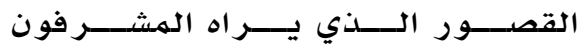
التّربويون في الجوانب التي حصل فيها

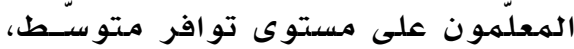

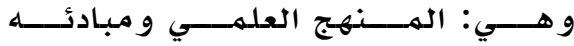

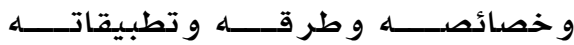

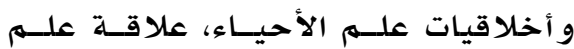

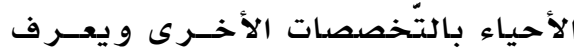
تطبيقات عله الأحياء و القضدايا الجدليّة

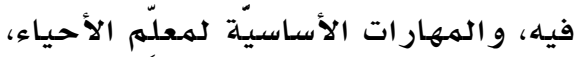

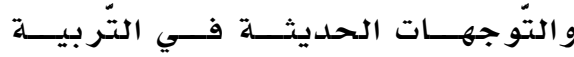

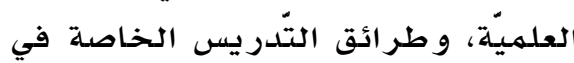
التّربية العلميّة. r. دراسلة جدوى تبنـي المعـايير المهنيـة

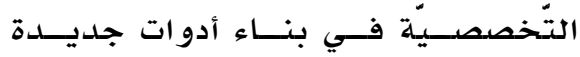

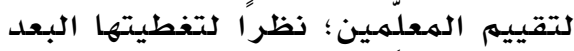

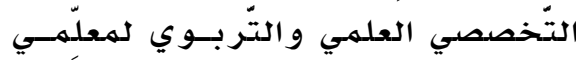

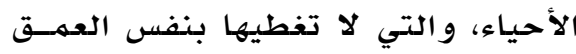

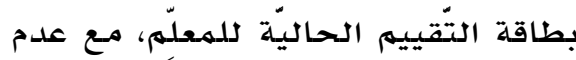

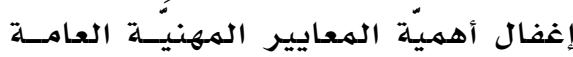
التي لهم يركز عليها البحث الحالي. عادة النظر في مناسـبـة تقيسيم معلّهم

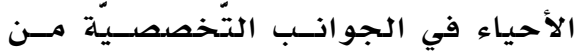
قبل مشرفين تربويين غير متخصصين

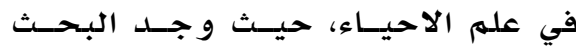

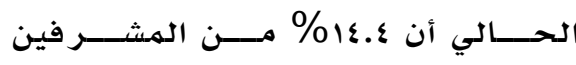

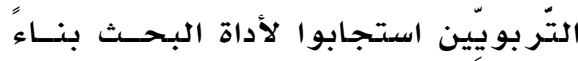

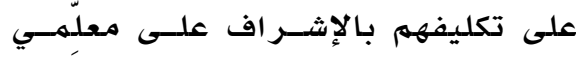
الأحياء، مـع أنهم غير متخصصصـين فـي

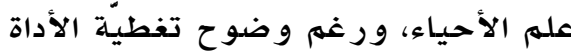


الدوري، ريه (11) (r). درجة ممارسة معلّمي

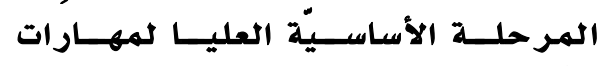

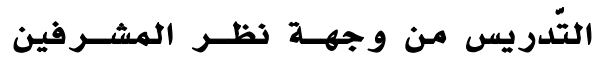

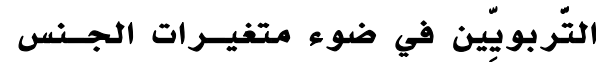

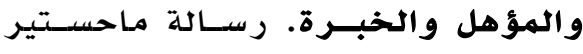

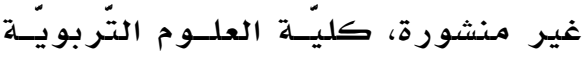
و النفسيّة، جامعة عمان العربيّة، الأردن. زيتون، كمال (ع..r). تحليل نقدي لهعايير

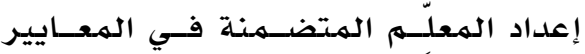

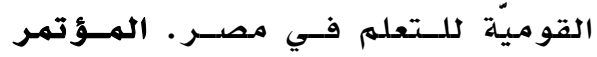

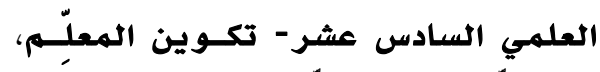

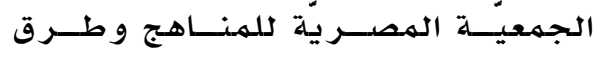

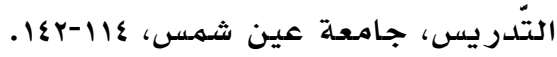

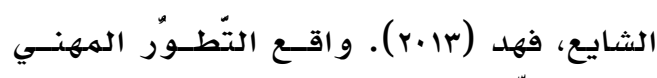

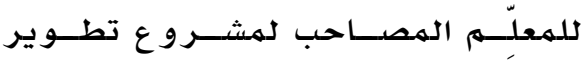
الر ياضيات و العلوم الطبيعية في التّعليهم

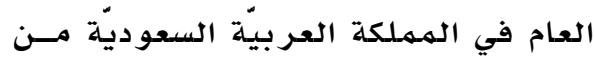

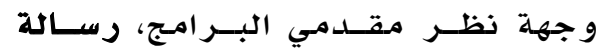

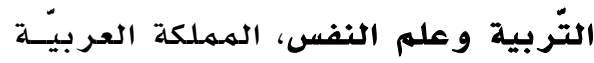

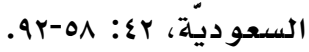

الشايع، فهد (.بعاهـ). تطوير تعليم العلوم والرياضيات: خطوة أولى في فئساء مجتمع المعر فة. مجلة المعرفة (179).

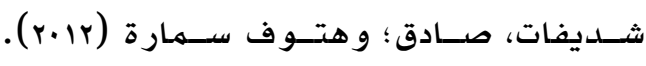
درجة تحقق المعايير الوطنيـة لتنهميـة

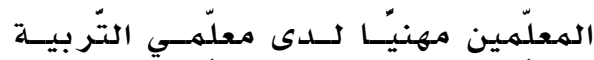

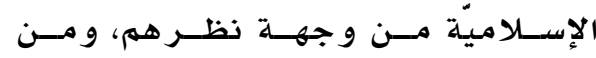

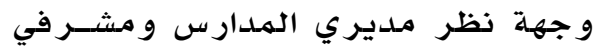

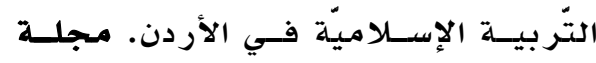

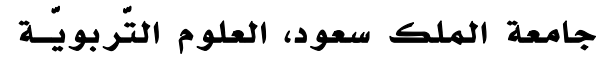

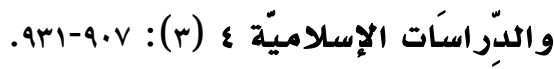

الضــلعـان، أحمــــ؛ و فهــــ الشــايع ؛ و مـحمــد

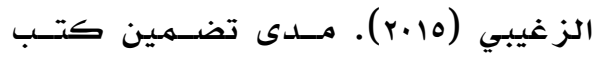
الفيزياء في المملكة العربيّة السـعوديّة

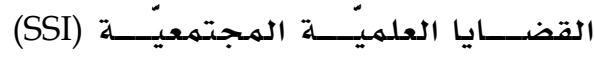

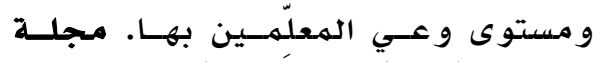

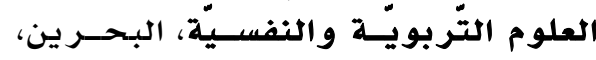
$.19 V-171:(r) 17$ http://tarbiyah21.org/new/files/unescorepo rts/Arab\%20teachers\% 20

Arab\%20League.pdf

الحصان، أماني؛ وجبر الجبر ؛ وعبده نعهـان

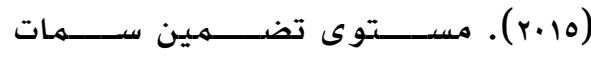

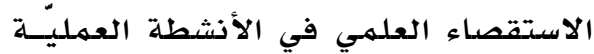

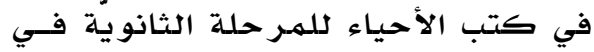

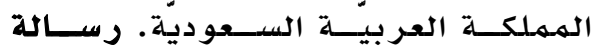

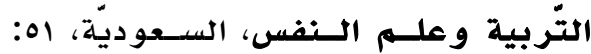
$.100-|r|$

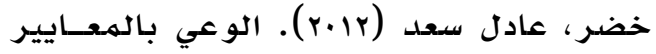
الههنيّة و علاقته بكسل مـن الاسـتقلادليّة

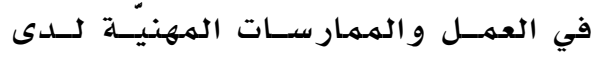

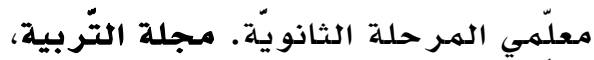

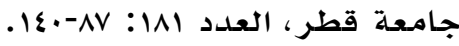

الخطيب، ريما (r.r.r). مستوى أداء معلّمــي العلوم في مرحلتي التَمكين والانطكلاق في ضوء معايير NSTA من وجهة نظر مير مئري

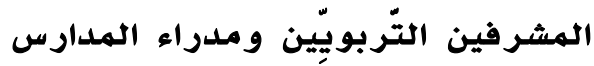

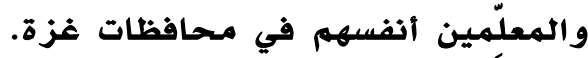
رسالة ماجستير، جامعة الأزهر، كليّة فمئة

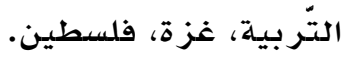

الخفـاجي، ابتســام (عا+r). تــوافر معـايير إعداد الهمعلم في الطلبـة المطبقين لقسهم

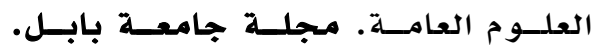

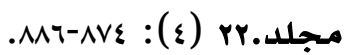

الدغيم، خالد (r/r). تقويم بر ذـامـج إعـداد

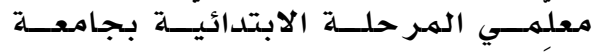

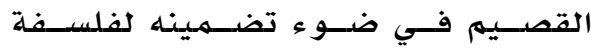

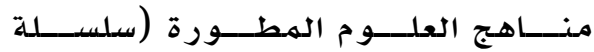

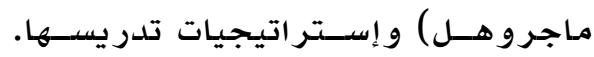

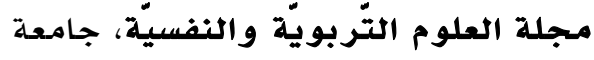

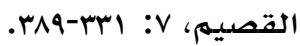

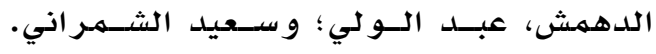

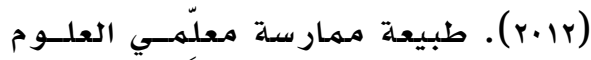

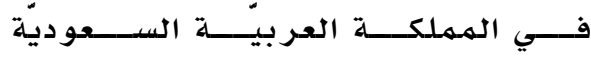

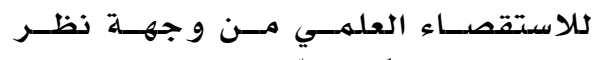

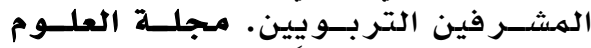

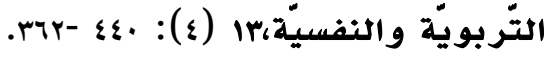


Australian Institute for Teaching and School Leadership AITSL (n.d.). Australian professional standards for teachers. Retrieved on May 9, 2016 from:

http:/ / www.aitsl.edu.au/australianprofessional-standards-forteachers/standards/list

Boyd, W. \& Reese, J. (2006). Great expectations: The impact of the National Board for Professional Teaching Standards. Education Next, 6(2), 51-57.

Bullough. R. (2016). Status and Quality of Teacher Education in the US: Neoliberal and Professional Tensions. In John Chi-Kin Lee \& Christopher Day (Eds.) Quality and Change in Teacher Education: Western and Chinese Perspectives (pp. 59-75). USA: Springer.

Centre of Study for Policies and Practices in Education CEPPE (n.d.). Learning standards, teaching standards and standards for school principals: A comparative study. Centre of Study for Policies and Practices in Education (CEPPE), Chile. Retrieved on May 9, 2016 from:

Cochran, K., DeRuiter, J., \& King, A. (1993). Pedagogical content knowledge: An integrative model for teacher preparation. Journal of Teacher Education, 44(4), 263-272.

Danielson, C. (1996). Enhancing professional practice: A Framework for Teaching. Alexandria, VA: ASCD.

EL-Deghaidy, H., Mansour, N., \& Alshamrani, S. (2014). Science teachers' typology of CPD activities: A socio-constructivist perspective. International Journal of Science and Mathematics Education, 13(6), 15391566.

http://research.acer.edu.au/cgi/vie wcontent. cgi? article $=1000 \&$ context $=\mathrm{t}$ eaching_standards:

http://www.nbpts.org/sites/defaul t/files/what_teachers_should_know .pdf

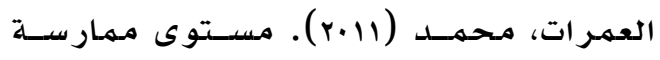

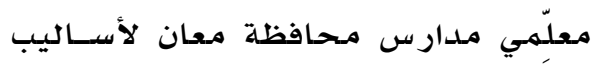

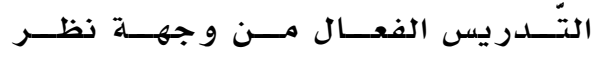

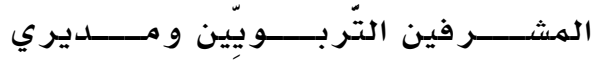

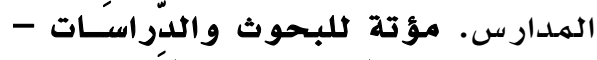

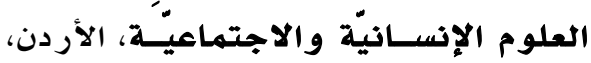

.rY\&-19r: : r) r

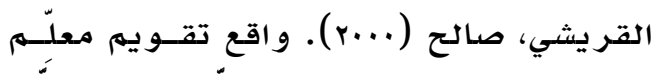

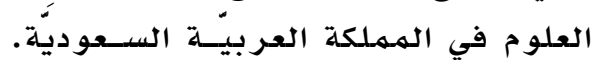

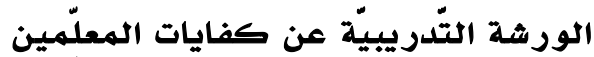

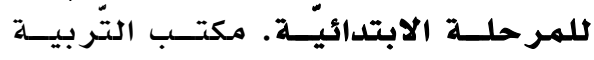

العربي لدول الخليج، جدة، السعودية.

الكثيري، راشد (1994). إعداد معلّم الأحيـاء

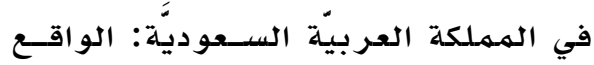

و المتوقوع. دراسـات في المناهج وطــرق

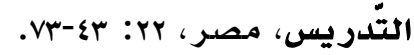

المركز الوطني للقياس والتّقويم (قيـاس)

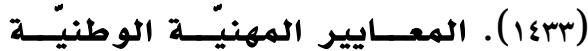

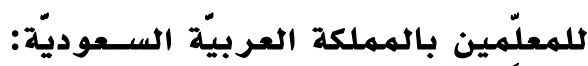

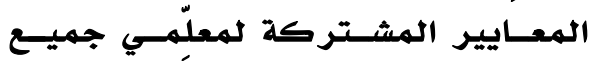
التخّصصات. الرياض، السعوديّة.

المركز الوطني للقياس والتّويم (قيـاس)

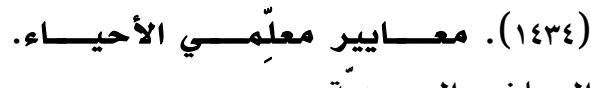
الرياض، السعو ديّة.

النجار، عبــد الله؛ و أسـامـة حنفـي (rا+rrم).

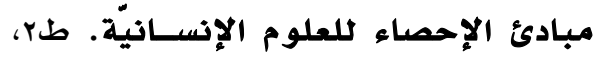

الرياض: شبكة البيانات.

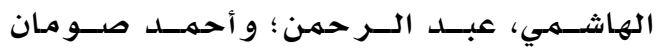

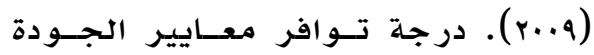

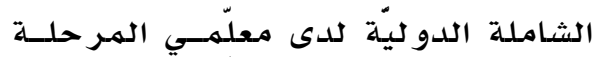

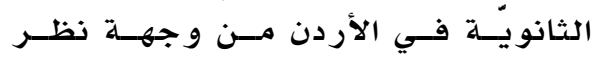

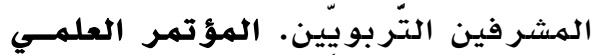

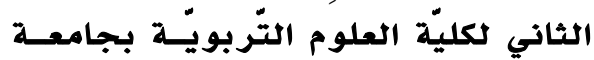

جرش - دور المعلّم العربي في عصدر لئر التَّفق المعر في، جرش، الأردن. 
Ingvarson, L. (1998). Professional development as the pursuit of professional standards: The standards based professional development system. Teaching and Teacher Education, 14(1), 127-140.

Kleinhenz, E., \& Ingvarson, L. (2007). Standards for teaching: Theoretical underpinnings and applications. New Zealand Teachers Council. Retrieved on May 8, 2016 from:

Koehler, M.J., \& Mishra, P. (2008). Introducing TPCK. In AACTE Committee on Innovation and Technology (Ed.). The handbook of technological pedagogical content knowledge (TPCK) for educators (pp. 329). Mahwah, NJ: Lawrence Erlbaum Associates.

Labaree, D. (1992). Power, knowledge, and the rationalization of reaching: $\mathrm{A}$ genealogy of the movement to professionalize teaching. Harvard Educational Review, 62(2), 123-155.

Loughran, J. (2013). Developing understanding of practice: Science teacher learning. In Norman Lederman \& Sandra Abell (Eds.) Handbook of Research on Science Education (pp. 811-829). New York: Routledge.

Mansour, N., Alshamrani, S., Aldahmash, A., \& Alqudah, B. (2013). Saudi Arabian science teachers and supervisors' views of professional development needs. Eurasian Journal of Educational Research. 51, 1-27.

Mayer, D., Mitchell, J., Macdonald, D., \& Bell, R. (2005). Professional standards for teachers: A case study of professional learning. Asia Pacific journal of teacher education, 33(2), 159. 179.

National Board for Professional Teaching Standards NBPTS (n.d.). What teachers should know and be able to do. Retrieved on May 9, 2016 from:

Shulman, L. (1986). Those who understand: Knowledge growth in Education. Educational Research, 15(2), 4-14. 